\title{
Impacts of dust deposition on dissolved trace metal concentrations (Mn, Al and Fe) during a mesocosm experiment
}

\author{
K. Wuttig ${ }^{1}$, T. Wagener ${ }^{1,2}$, M. Bressac ${ }^{3,4}$, A. Dammshäuser ${ }^{1}$, P. Streu ${ }^{1}$, C. Guieu ${ }^{3,4}$, and P. L. Croot ${ }^{1, *}$ \\ ${ }^{1}$ GEOMAR Helmholtz Centre for Ocean Research Kiel, Marine Biogeochemistry, Düsternbrooker Weg 20, \\ 24105 Kiel, Germany \\ ${ }^{2}$ Université d'Aix-Marseille, CNRS/INSU, IRD, Institut Méditerranéen d'Océanologie (MIO), UM 110, \\ 13288 Marseille, France \\ ${ }^{3}$ Laboratoire d'Océanographie de Villefranche-sur-Mer, CNRS-INSU, UMR 7093, Observatoire Océanologique, 06230, \\ Villefranche-sur-Mer, France \\ ${ }^{4}$ Université Pierre et Marie Curie - Paris 6, UMR7093, LOV, Observatoire Océanologique, Villefranche-sur-Mer, France \\ *now at: Earth and Ocean Sciences, School of Natural Sciences, National University of Ireland, \\ Galway (NUIG), Galway, Ireland
}

Correspondence to: K. Wuttig (kwuttig@geomar.de)

Received: 26 September 2012 - Published in Biogeosciences Discuss.: 11 October 2012

Revised: 1 March 2013 - Accepted: 21 March 2013 - Published: 18 April 2013

\begin{abstract}
The deposition of atmospheric dust is the primary process supplying trace elements abundant in crustal rocks (e.g. $\mathrm{Al}, \mathrm{Mn}$ and $\mathrm{Fe}$ ) to the surface ocean. Upon deposition, the residence time in surface waters for each of these elements differs according to their chemical speciation and biological utilization. Presently, however, the chemical and physical processes occurring after atmospheric deposition are poorly constrained, principally because of the difficulty in following natural dust events in situ. In the present work we examined the temporal changes in the biogeochemistry of crustal metals (in particular $\mathrm{Al}, \mathrm{Mn}$ and $\mathrm{Fe}$ ) after an artificial dust deposition event. The experiment was contained inside trace metal clean mesocosms $(0-12.5 \mathrm{~m}$ depths) deployed in the surface waters of the northwestern Mediterranean, close to the coast of Corsica within the frame of the DUNE project (a DUst experiment in a low Nutrient, low chlorophyll Ecosystem). Two consecutive artificial dust deposition events, each mimicking a wet deposition of $10 \mathrm{~g} \mathrm{~m}^{-2}$ of dust, were performed during the course of this DUNE-2 experiment. The changes in dissolved manganese $(\mathrm{Mn})$, iron $(\mathrm{Fe})$ and aluminum (Al) concentrations were followed immediately after the seeding with dust and over the following week. The $\mathrm{Mn}, \mathrm{Fe}$ and $\mathrm{Al}$ inventories and loss or dissolution rates were determined. The evolution of the inventories after the two consecutive additions of dust showed distinct behaviors
\end{abstract}

for dissolved $\mathrm{Mn}, \mathrm{Al}$ and $\mathrm{Fe}$. Even though the mixing conditions differed from one seeding to the other, $\mathrm{Mn}$ and $\mathrm{Al}$ showed clear increases directly after both seedings due to dissolution processes. Three days after the dust additions, $\mathrm{Al}$ concentrations decreased as a consequence of scavenging on sinking particles. Al appeared to be highly affected by the concentrations of biogenic particles, with an order of magnitude difference in its loss rates related to the increase of biomass after the addition of dust. In the case of dissolved $\mathrm{Fe}$, it appears that the first dust addition resulted in a decrease as it was scavenged by sinking dust particles, whereas the second seeding induced dissolution of $\mathrm{Fe}$ from the dust particles due to the excess Fe binding ligand concentrations present at that time. This difference, which might be related to a change in $\mathrm{Fe}$ binding ligand concentration in the mesocosms, highlights the complex processes that control the solubility of Fe. Based on the inventories at the mesocosm scale, the estimations of the fractional solubility of metals from dust particles in seawater were $1.44 \pm 0.19 \%$ and $0.91 \pm 0.83 \%$ for $\mathrm{Al}$ and $41 \pm 9$ and $27 \pm 19 \%$ for $\mathrm{Mn}$ for the first and the second dust addition. These values are in good agreement with laboratory-based estimates. For Fe no fractional solubility was obtained after the first seeding, but $0.12 \pm 0.03 \%$ was estimated after the second seeding. Overall, the trace metal dataset presented here makes a significant 
contribution to enhancing our knowledge on the processes influencing trace metal release from Saharan dust and the subsequent processes of bio-uptake and scavenging in a low nutrient, low chlorophyll area.

\section{Introduction}

Marine oligotrophic areas, also described as low nutrient, low chlorophyll (LNLC) areas, represent $60 \%$ of the global ocean (Longhurst et al., 1995) and are suggested to contribute up to $50 \%$ oceanic carbon export from the surface to the deep ocean (Emerson et al., 1997). These areas are characterized by low nutrient concentrations in oceanic surface waters resulting in reduced biological activity (Carr et al., 2006; Longhurst et al., 1995). Vast surfaces of these LNLC areas are subject to fluxes of lithogenic material through the atmospheric deposition of desert dust particles. Microcosm experiments performed previously in the oligotrophic eastern Mediterranean by Herut et al. (2005) found that the addition of fresh mineral dust to seawater resulted in the release of nutrients and to a positive growth response by biota; however, they did not find a response of biota to pre-leached dust, suggesting it was the presence of water soluble components in the dust that provided the nutrient stimulus. Due to the elemental composition of the earth crust, the flux of dust particles constitutes a major source of trace metals to the surface ocean (Duce et al., 1991; K. Desboeufs, personal communication, 2013). For this reason, in addition to macronutrients (phosphorus and nitrogen) transported by dust particles, it has been suggested that the response of the biota to dust might be (partially) controlled by trace metals. During the last twenty years, due to its importance in high nutrient, low chlorophyll (HNLC) areas, iron (Fe) has received much attention (Jickells et al., 2005), but in recent years, a number of studies have pointed to the importance of studying other trace elements in order to more completely describe the overall biogeochemical functioning of these LNLC areas (e.g. Heller and Croot, 2010; Noble et al., 2008; Obata et al., 2008; Saito and Moffett, 2002).

In order to assess the impact of atmospherically deposited micronutrients on the biogeochemical functioning of the LNLC areas, a variety of complex factors controlling the solubility of trace metals - from the solid form in a dust particle to the dissolved form once it enters the water - have to be taken into account (Baker and Croot, 2010). Indeed, in addition to atmospheric factors controlling the inherent solubility of the metal in the particle (size of the particles (Baker and Jickells, 2006), mineralogy (Journet et al., 2008), chemical composition (Sedwick et al., 2007)), there are a number of factors that can be important once the particle is deposited in seawater. These factors can be the initial concentration of dissolved metals in seawater (Liu and Millero, 2002; Mendez et al., 2010), photochemical processing (Fe(III) to $\mathrm{Fe}(\mathrm{II})$ )
(Zhuang et al., 1992) and lability in the atmosphere and in seawater (Spokes and Jickells, 1996). Additional factors can be the mixing layer structure (Croot et al., 2007; Moore et al., 2006) as well as specific chelating substances in seawater at the time of the deposition, as in the case of Fe (Gledhill and Buck, 2012; Wagener et al., 2008).

The Mediterranean Sea is a LNLC area, especially in summer when the surface is strongly stratified. The atmospheric load over the Mediterranean has been estimated to reach up to one billion tonnes per year, which is one of the highest dust loads reaching a LNLC area (Guerzoni et al., 1999). In Corsica, dust deposition events of $\sim 22 \mathrm{~g} \mathrm{~m}^{-2}$ have been observed (e.g. Bonnet and Guieu, 2006). The Mediterranean is a suitable place to assess the impact of dust deposition on LNLC areas. This is the objective of the project DUNE (a DUst experiment in a low Nutrient low chlorophyll Ecosystem) based on an original experimental approach: dust addition experiments into large, clean mesocosms. This experimental design constitutes an opportunity to study processes once particles have deposited at the surface ocean in a realistic way (Guieu et al., 2009, 2010).

During the first campaign in 2008 (DUNE-1), it was demonstrated that the mesocosms were sufficiently trace metal clean to study the Fe cycle (Wagener et al., 2010). Two major results concerning Fe chemistry were gained from this first experiment:

1. A clear decrease of the dissolved iron $(\mathrm{Fe})$ inventory in the mesocosms, in which a wet deposition was simulated, compared to the mesocosms without addition of dust, has been observed. A simple 1-D model of the mesocosms demonstrated that during the experiment the addition of dust was a sink rather than a source of Fe due to scavenging on dust particles (Ye et al., 2011).

2. Additionally, a second addition of simulated aeolian dust in batch experiments performed with filtered seawater, obtained from the corresponding mesocosms $168 \mathrm{~h}$ after the first seeding, showed a clear increase in the Fe solubility. Wagener et al. (2010) postulated that the dust addition could have induced the production of Fe binding ligands and therefore increased significantly the solubility of Fe. This would imply that a second addition of dust to the mesocosms might have a stimulatory effect on $\mathrm{Fe}$ dissolution and a contrasting impact from the first addition.

A second experimental campaign was performed in June and July 2010 (DUNE-2) (Guieu et al., 2013). Based on the experience gained during the DUNE-1 experiment, the strategy for studying trace metals was slightly changed. Understanding the processes that govern the fluxes of Fe to seawater is a critical challenge in chemical oceanography today. While the importance of $\mathrm{Fe}$ to primary productivity in the ocean is well demonstrated (Blain et al., 2007; Boyd et al., 2000), we are only now beginning to examine the exchange 
of $\mathrm{Fe}$ between different chemical forms in seawater (Croot and Heller, 2012; Gledhill and Buck, 2012; Baker and Croot, 2010). The ability of Fe to form organic complexes (Croot and Heller, 2012; Gledhill and Buck, 2012) helps to elevate Fe levels above the low solubility of inorganic Fe(III) in seawater (Liu and Millero, 2002); however, colloidal Fe still dominates the dissolved fraction (Bergquist et al., 2007). The chemical reactivity and biological requirement for $\mathrm{Fe}$ result in it being easily scavenged onto other particles and subsequently lost from the euphotic zone. For this reason, Fe binding ligand measurements have been performed in addition to the dissolved Fe concentration measurements. Moreover, two additional dissolved trace metals have been examined during DUNE-2: the biogeochemically important micronutrient manganese (Mn) and the crustal metal aluminum (Al). In contrast to $\mathrm{Fe}$, there is no organic speciation known for $\mathrm{Al}$ and it is also considered to be negligible for Mn (Roitz and Bruland, 1997; Sañudo-Wilhelmy et al., 1996). Al is a major and relatively invariant component of the earth crust and is not known to be actively assimilated by organisms. However, $\mathrm{Al}$ is strongly influenced by scavenging mechanisms and is therefore considered to be a potentially useful tracer for lithogenic input on relatively short time scales (Dammshäuser et al., 2011). On the other hand, Mn is a bioactive metal with a complex chemistry in seawater. While most of the Mn exists as soluble Mn(II) which is not thought to be organically complexed, dissolved Mn(III) and Mn(IV) organic species are possible, but have not yet been observed in oxygenated seawater. Soluble $\mathrm{Mn}(\mathrm{III})$ is rare in natural waters because it hydrolyzes and precipitates as $\mathrm{Mn}$ (III) oxides or disproportionate into Mn(IV) oxides plus Mn(II) (Nealson et al., 1988; Stumm and Morgan, 1996). Another important difference compared to DUNE-1 is that DUNE- 2 was carried out with two consecutive seedings with the same amount of evapocondensed dust. After measuring the initial concentrations, the seeding with dust was performed and all experimental variables were determined with a higher resolution in the first day and then daily for one week. After the second addition of dust the variables were measured again for one week with a similar resolution in order to assess if the biogeochemical response to a second seeding could be influenced by the response to the former seeding.

This paper presents the dissolved trace metal inventories of $\mathrm{Fe}, \mathrm{Mn}$ and $\mathrm{Al}$ during the DUNE-2 experiment. Based on the revised experimental strategy after the DUNE-1 experiment, the specific objectives of this study are (1) to assess dissolution and loss rates of these trace metals after two consecutive additions of dust and (2) to quantify the processes involved at different time scales.

\section{Materials and methods}

\subsection{Experimental design and sampling}

In June 2010, seven trace metal clean mesocosms were deployed in the Bay of Elbo in the conservation area of Scandola, Corsica $\left(42.374^{\circ} \mathrm{N}, 8.554^{\circ} \mathrm{E}\right)$ during typical oligotrophic summer conditions (Millot, 1999). Marine oligotrophic areas, also described as low nutrient, low chlorophyll (LNLC) areas, are typically defined by a chlorophyll $a$ content of less than $0.1 \mathrm{mg} \mathrm{m}^{-3}$ (Carr et al., 2006; Longhurst et al., 1995). Giovagnetti et al. (2012) showed that during the DUNE-2 experiment the chlorophyll $a$ content always remained below this threshold even after the seedings. Their initial chlorophyll $a$ concentration was $0.02-0.03 \mathrm{mg} \mathrm{m}^{-3}$. The DUNE-2 mesocosm experiment design was based on the exact same protocol as described in detail earlier (Guieu et al., 2010) for the DUNE-1 experiment in 2008. The mesocosms were entirely made out of plastic and were composed of a cylindrical section of $12 \mathrm{~m}$ length and $2.3 \mathrm{~m}$ in diameter. The conical bottom started at $12 \mathrm{~m}$ depth and ended with a sediment trap at $14.5 \mathrm{~m}$ depth. In each mesocosm, the total seawater volume was $52 \mathrm{~m}^{3}$ and, in general, the biological, chemical and physical properties of the water column were retained within the mesocosms. To protect the mesocosms against naturally occurring dust events, they were covered with a transparent cover which was designed to let natural light pass and to allow gas exchanges between the water body and the atmosphere. The three mesocosms to which the dust was added are referred to here as D1, D2 and D3 and "dust seeded mesocosms". Further, three trace-metal clean mesocosms were kept without seeding as the control mesocosms (labeled here C1, C2 and C3). For comparison between the control mesocosms and the environment, samples were also taken outside the mesocosms.

The seeding with dust was performed using the following protocol. After deploying the mesocosms, they were left open for $24 \mathrm{~h}$ in order to let the water masses inside equilibrate with the water masses outside of the mesocosms. After closing the mesocosms, t0 was sampled and then the mesocosms were seeded. Two consecutive seedings with cloud processed dust (Guieu et al., 2010) were performed at an interval of one week. Each seeding was followed for a week with high resolution sampling in the first $24 \mathrm{~h}$ and subsequent daily sampling. Therefore, DUNE-2 had a higher time resolution than DUNE-1 where sampling was performed daily for most parameters (Guieu et al., 2010). For each of the two consecutive seedings, $41.5 \mathrm{~g}$ of evapocondensed dust was diluted in ultrapure water (hereafter referred to as MQ water see below) and sprayed with an all-plastic spray bottle onto the surface of each of the mesocosms. This corresponds to a simulated wet deposition of $10 \mathrm{~g} \mathrm{~m}^{-2}$ for each seeding. The first seeding took place on 26 June 2010 at 09:00 UTC (t0), the second on 3 July 2010 at 07:00 UTC (t166). 
In each of the six sampled mesocosms, flexible reinforced PVC tubings were installed at $0.1,5$ and $10 \mathrm{~m}$ depth. Sampling was performed with a Teflon ${ }^{\mathrm{TM}}$ (polytetrafluoroethylene) diaphragm pumping system. For dissolved trace metals, samples were filtered inline through $0.2 \mu \mathrm{m}$ filter cartridges (Sartorius Sartobran filter capsule 5231307H5, Germany). Additionally to DUNE-1, two dust seeded mesocosms (D1 and D2) were deployed with three supplementary tubings installed at $2.5,7.5$ and $12.5 \mathrm{~m}$ depth in order to improve the resolution in the water body and to be able to follow the processes after a simulated dust storm on a smaller scale.

\subsection{Chemical Analysis}

\subsubsection{Reagents and bottles}

Strict attention was paid to avoiding contamination in this study. All manipulations were performed in class 100laminar flow benches. All reagents that were used were of highest purity available (Fisher Scientific and SigmaAldrich) and were prepared using deionized $\left(18 \mathrm{M} \Omega \mathrm{cm}^{-1}\right.$ resistivity) water (MQ water) from a Milli-Q purification system (Millipore). Sub-boiled quartz-distilled hydrochloric acid (hereafter $\mathrm{Q}-\mathrm{HCl}$ ) was made by single distillation from $25 \% \mathrm{HCl}$. All plasticware and bottles (low density high polyethylene (LDPE) and polytetrafluoroethylene (PTFE)) used for acidified seawater samples for the total trace metal analysis were cleaned according to the trace metal clean procedures (Bruland et al., 1979; Cutter et al., 2010) and then protected by double bags (Minigrip ${ }^{\mathrm{TM}}$ ). The filtered samples for dissolved trace metal analysis were directly acidified with Q-HCl to $\mathrm{pH} 1.7$ under a class 100-laminar flow bench in the lab at the port facilities used for servicing the mesocosms. Samples for Fe binding ligands were directly frozen $\left(-20^{\circ} \mathrm{C}\right)$ upon collection in Corsica, transported frozen to Marseille, and thawed immediately prior to analysis. Sample processing and analysis steps were performed in laminar flow benches inside class 100 clean rooms in Kiel (Germany) and in Villefranche-sur-Mer (France).

In this paper we only discuss the dissolved trace metals (referred to as $\mathrm{Mn}, \mathrm{Fe}$ and $\mathrm{Al}$ ).

\subsubsection{Dissolved manganese analysis}

Samples for dissolved manganese (Mn) were analyzed on site. The acidified samples were spectrophotometrically analyzed using a slightly modified flow-injection analysis system (FIA) built following Aguilar-Islas et al. (2006). We used one 8-channel peristaltic pump (Rainin), two electronically actuated 6-port valves, one electronically actuated 10port sample valve (all VICI, Valco Instruments), one dry bath (Fisher) kept at $35^{\circ} \mathrm{C}$ and a variable wavelength spectrophotometer (USB-4000, Ocean Optics, Inc.) with an internal Ocean Optics light source and a $1 \mathrm{~cm}$ quartz flowthrough cell (100-QS, $10.00 \mathrm{~mm}$, Hellma GmbH and Co.
KG). The flow rates were identical with those in AguilarIslas et al. (2006). The filtered and acidified seawater sample was preconditioned for $30 \mathrm{~s}$ by flushing with $0.05 \mathrm{~mol} \mathrm{~L}^{-1}$ ammonium borate rinse solution on a pre-concentration column (GLOBAL-FIA) filled with Toyopearl AF-Chelate$650 \mathrm{M}$ resin. The timing parameters were for preconditioning, loading, rinse and elution of the column: $30,120,30$, 180 s, respectively.

Calibration curves were determined daily by the addition of standards $\left(0-10 \mathrm{nmol} \mathrm{L}^{-1}\right)$ produced by serial dilution of a $1000 \mathrm{ppm} \mathrm{Mn}$ (II) standard (Fluka) into $0.2 \mu \mathrm{m}$ filtered Mediterranean seawater which had been taken before the first seeding at $5 \mathrm{~m}$ depth outside of the mesocosms at our external reference point ( $\mathrm{t} 0$, outside, $5 \mathrm{~m}$ ). For external validation, selected samples were also analyzed in the clean laboratory in Kiel by graphite furnace atomic absorption (ETAAS, Perkin-Elmer Model 4100ZL; this method is described in detail below).

Samples, standard additions and blanks were measured in triplicates. Analytical precision (expressed as percent relative standard deviation) was typically $<8 \%$ at $3.6 \mathrm{nmol} \mathrm{L}^{-1}$ under the conditions employed here. The accuracy of the analytical procedure was evaluated by daily measurements of SAFe intercalibration samples S and D2. It should be noted, however, that the SAFe concentrations are over a lower range $\left(<1 \mathrm{nmol} \mathrm{L}^{-1}\right)$ than the seawater samples from the mesocosms $\left(<3.5 \mathrm{nmol} \mathrm{L}^{-1}\right)$, which leads to lower precision for the SAFe samples using our system optimized for Mediterranean surface waters. SAFe values determined while in Corsica were as follows: $0.85 \pm 0.14 \mathrm{nmol} \mathrm{L}^{-1}$ (S) and $0.35 \pm 0.09 \mathrm{nmol} \mathrm{L}^{-1}$ (D2) of $\mathrm{Mn}(n=8)$ (consensus values are $0.79 \pm 0.06 \mathrm{nmol} \mathrm{L}^{-1}$ and $0.35 \pm 0.06 \mathrm{nmol} \mathrm{L}^{-1}$, respectively). We used a large volume of secondary standard $(0.2 \mu \mathrm{m}$ filtered Mediterranean seawater (t0, outside, $5 \mathrm{~m}))$ throughout this work as the seawater in which standard additions were prepared. The complete Mn-FIA measurements over the course of the work in Corsica resulted in a value of $3.60 \pm 0.30 \mathrm{nmol} \mathrm{L}^{-1}$, which was in good agreement with values measured by ETAAS in Kiel: $3.55 \pm 0.08 \mathrm{nmol} \mathrm{L}^{-1}$. The detection limit ( $3 \sigma$ of the blank) for the Mn flow injection system used here was estimated in the lab in Kiel by repeated measurements of low Mn Antarctic seawater $\left(<0.2 \mathrm{nmol} \mathrm{L}^{-1}\right.$; collected during ANTXXIV-3) at $150 \mathrm{pmol} \mathrm{L}^{-1}$. The use of a low Mn or Mn free seawater is preferred to running MQ blanks, as both in Corsica and in Kiel we found that there was detectable Mn in the MQ systems due to problems with the ion-exchange units of the systems.

A few samples of $\mathrm{Mn}$, as a comparison to the direct analysis in Corsica (FIA), were analyzed by graphite furnace atomic absorption (ETAAS, Perkin-Elmer Model 4100ZL) in the clean laboratory in Kiel using solvent extraction modified after Klinkhammer (1980). Briefly, $200 \mathrm{~g}$ of filtered and acidified seawater were extracted with 8hydroxychinoline in distilled chloroform as Mn-oxinates, 
back-extracted with $3 \mathrm{~mol} \mathrm{~L}^{-1}$ distilled $\mathrm{HNO}_{3}$ and then analyzed with ETAAS. SAFe reference seawater D1 was determined as $0.423 \pm 0.05 \mathrm{nmol} \mathrm{L}^{-1}$ (consensus value $\left(0.35 \pm 0.06 \mathrm{nmol} \mathrm{L}^{-1}\right)$; these $\mathrm{Mn}$ values for the validation are given in the supplementary information.

\subsubsection{Dissolved iron and Fe binding ligand analysis}

$\mathrm{Fe}$ concentrations were analyzed at Laboratoire d'Océanographie de Villefranche-sur-Mer between 4 and 10 months after the experiment. A flow injection system with online preconcentration and chemiluminescence detection was used as described in Bonnet and Guieu (2006). The detection limit (DL) was $25 \mathrm{pmol} \mathrm{L}^{-1}$ on average and blanks were between 50 and $150 \mathrm{pmol} \mathrm{L}^{-1}$. An internal acidified seawater standard was measured in order to control the stability of the analysis during each series of measurements. The reliability of the method was controlled by analyzing the D2 SAFe seawater standard (Johnson et al., 2007), which was determined as $0.84 \pm 0.04 \mathrm{nmol} \mathrm{L}^{-1}$ of $\mathrm{Fe}(n=5)$ (consensus value is $0.90 \pm 0.02 \mathrm{nmol} \mathrm{L}^{-1}$ ).

The concentration of Fe complexing ligands, [L] was determined by cathodic stripping voltammetry using the competitive ligand 2-(2-thiazolyazo-)-p-cresol (TAC) (Croot and Johansson, 2000) at Institut Méditerranéen d'Océanologie, Marseille (France) 18 months after the experiment. After thawing of the samples, [L] complexing ligands were determined following the exact same protocol as described in Wagener et al. (2008). A $\mu$-Autolab voltammeter coupled to a Metrohm VA663 electrode stand with a static mercury drop working electrode, a double junction $\mathrm{Ag} / \mathrm{AgCl}$ reference electrode and carbon rod counter electrode was used. The titration data were calculated using a single ligand fit with the van den Berg/Ruzic linearization method (see, for example, Croot and Johannsson, 2000).

\subsubsection{Dissolved aluminum analysis}

The aluminum analysis was conducted at GEOMAR, Kiel, a few months after the experiment using the fluorometric method described by Hydes and Liss (1976). In short, the reagent lumogallion was added to the sample, which was then buffered to $\mathrm{pH} 5$ with ammonium-acetate, and heated to $40-50{ }^{\circ} \mathrm{C}$ for $3 \mathrm{~h}$ to accelerate complex formation. The fluorescence of the sample was measured with a Hitachi FL 2700 Fluorescence Spectrophotometer (excitation wavelength $497 \mathrm{~nm}$, emission wavelength $572 \mathrm{~nm}$ ). The detection limit varied between 0.1 and $0.3 \mathrm{nmol} \mathrm{L}^{-1}$, the blank values between 0.4 and $0.6 \mathrm{nmol} \mathrm{L}^{-1}$ for the different days of analysis. In the SAFe reference seawater S1 (S1 543, S1 474), $1.81 \pm 0.24 \mathrm{nmol} \mathrm{L}^{-1}$ of $\mathrm{Al}(\mathrm{n}=4)$ were determined (consensus value is $\left.1.74 \pm 0.09 \mathrm{nmol} \mathrm{L}^{-1}\right)$.

\section{Results}

The complete set of data is available as supplementary information to this paper.

The nomenclature for samples of the DUNE-2 experiment is as follows: dust seeded mesocosms D1, D2 and D3; unseeded control mesocosms C1, C2 and C3; and the sampling outside the mesocosms. Samples were taken at 0.1, 2.5, 5.0, $7.5,10.0$ and $12.5 \mathrm{~m}$ depth. The time $t x$ is expressed in hours $(x)$ since the first dust addition and in parentheses $t x(y)$ the time (in $h$ ) since the second dust addition. The samples outside the mesocosms were taken as an external reference point to the control mesocosms and the concentrations are not reported in the figures, but are available in the supplementary information.

\subsection{Evolution of dissolved manganese (Mn)}

Figure 1 shows the evolution of the concentration of $\mathrm{Mn}$ as a function of time after the first seeding and depth in each of the mesocosms. The initial Mn concentrations outside, in the control and dust seeded mesocosms were $3.4 \pm 0.6 \mathrm{nmol} \mathrm{L}^{-1}$. Directly on the first day (t23) after the first dust addition, the Mn concentrations increased to $4.9 \pm 0.4 \mathrm{nmol} \mathrm{L}^{-1}$ in the surface and at mid-depth (D1 and D2). D3 was not sampled at $t 23$ after the first addition. At 448 the same trend as in D1 and D2 was seen with a continuation of the increase in Mn which was most pronounced in the surface. After the continuous increase since the first seeding with dust, at $\mathrm{t} 71 \mathrm{Mn}$ reached its maximum in all three dust seeded mesocosms and in D1 at $5 \mathrm{~m}$ depth the concentration was as elevated as $7.2 \mathrm{nmol} \mathrm{L}^{-1}$. After this initial elevation of $\mathrm{Mn}$, overall the concentration then decreased slowly in all three dust seeded mesocosms with time down to 3.0$4.6 \mathrm{nmol} \mathrm{L}^{-1}$ after a week. These values were in the range of the values before the first seeding.

After the second dust addition to the surface of the dust seeded mesocosms, the increase in Mn was more pronounced than after the first addition. Concentrations of $\mathrm{Mn}$ in the surface $(0.1 \mathrm{~m})$ in the first few hours after the second seeding increased strongly, especially in D2 to $13.2 \mathrm{nmol} \mathrm{L}^{-1}$ at $\mathrm{t} 171(5)$ and $11 \mathrm{nmol} \mathrm{L}^{-1}$ at $\mathrm{t} 175(9)$. In these first $24 \mathrm{~h}$ after the second dust addition the concentrations of $\mathrm{Mn}$ at $5 \mathrm{~m}$ and $10 \mathrm{~m}$ remained constant at 3.2 to $4.4 \mathrm{nmol} \mathrm{L}^{-1}$. While the values in the surface decreased slowly after the first strong pulse following the second addition, the Mn values increased at $5 \mathrm{~m}$ at t191(24) and even more at t215(49). At all depths the Mn concentrations in the dust seeded mesocosms decreased again with time down to $3-5 \mathrm{nmol} \mathrm{L}^{-1}$ after t287(121) (with the exception of D3 $10 \mathrm{~m}$ with a Mn concentration of $\left.5.7 \mathrm{nmol} \mathrm{L}^{-1}\right)$. 

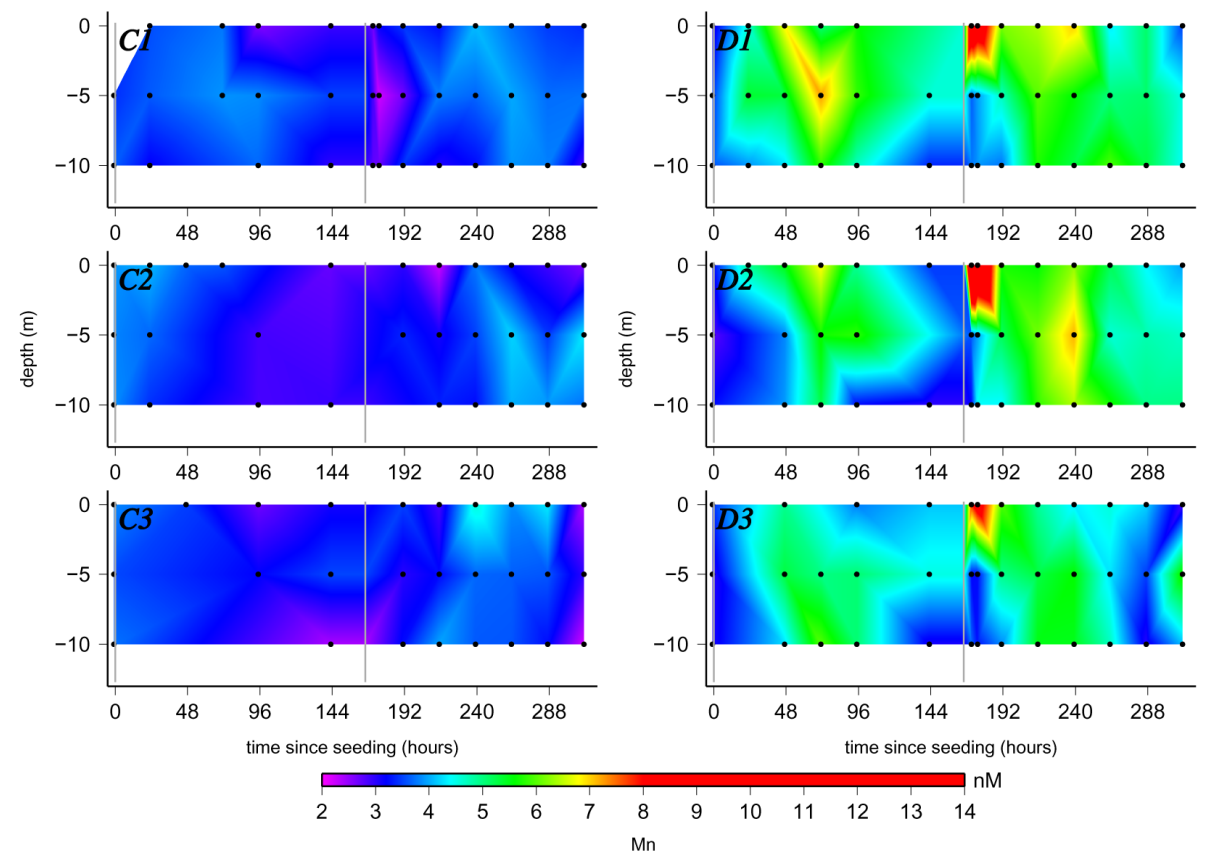

Fig. 1. Evolution of dissolved manganese $(\mathrm{Mn})$ in the 6 mesocosms (left hand side - control mesocosms: $\mathrm{C} 1, \mathrm{C} 2$ and $\mathrm{C} 3$; right hand side dust seeded mesocosms: D1, D2 and D3). The graphs are plotted as the time since the first seeding (h) versus the depth (m) in the mesocosms. Black dots show the points were samples were taken. The two grey vertical bars highlight the time points when the seeding took place (t0 and $\mathrm{t} 166(0))$.

\subsection{Evolution of dissolved iron concentration $(\mathrm{Fe})$ and Fe binding ligands $(\mathrm{L})$}

In Fig. 2, the evolution of $\mathrm{Fe}$ values in the control and dust seeded mesocosms are shown. The initial $\mathrm{Fe}$ values before the dust addition varied between 2.2 and $4.4 \mathrm{nmol} \mathrm{L}^{-1}$ inside the mesocosms and outside (values available in the supplementary information). After the first addition of dust at $\mathrm{t} 10$, there was a direct decrease in the Fe concentrations to $2.5-2.9 \mathrm{nmol} \mathrm{L}^{-1}$ in the surface of the dust seeded mesocosms and values as low as $1.5 \mathrm{nmol} \mathrm{L}^{-1}$ were measured in D2 and D3. At t23 the values inside the control mesocosms still ranged from 3.0 to $3.5 \mathrm{nmol} \mathrm{L}^{-1}$. With more time elapsing, this decrease in the $\mathrm{Fe}$ concentrations continued in the dust seeded mesocosms but also occurred in the control mesocosms and outside. After $\mathrm{t} 143$ the Fe values in the control mesocosms varied from $1.4-2.1 \mathrm{nmol} \mathrm{L}^{-1}$ and in the dust seeded mesocosms from $1.6-2.0 \mathrm{nmol} \mathrm{L}^{-1}$.

After the second dust addition, a significant increase in $\mathrm{Fe}$ was observed in the dust seeded mesocosms, whereas Fe values remained constant in control mesocosms. Directly after this addition there was a strong increase in the surface with a maximum at $\mathrm{t} 191$ (25). In D1 and D2, the Fe concentration increased up to $6.1 \mathrm{nmol} \mathrm{L}^{-1}$ at $2.5 \mathrm{~m}$ and up to $3.8 \mathrm{nmol} \mathrm{L}^{-1}$ in the surface of D3. In the first $24 \mathrm{~h}$ after the second addition the Fe values had increased in all the dust seeded mesocosms. However, after t215(49), the Fe concentrations de- creased quickly again down to $1.0-1.8 \mathrm{nmol} \mathrm{L}^{-1}$. This range remained the same until the end of the experiment.

Fe complexing ligands in the dissolved phase $\left[\mathrm{L}^{\prime}\right]$ were measured on a limited subset of samples collected at $5 \mathrm{~m}$ depth. The evolution of the arithmetical means [L'] for the dust seeded and the control mesocosms is presented in Fig. 3. Before and after the first seeding, ligands were close to saturation or over-saturated, i.e. $([\mathrm{L}]+[\mathrm{FeL})<$ total dissolved $\mathrm{Fe}$, with values ranging from 1.3 to $3.3 \mathrm{nmol} \mathrm{L}^{-1}$ at t0-t143. In the control mesocosms the values remained in this range for the whole experiment. The saturation and over-saturation made a full analysis of the ligand complexation parameters complicated as the ambient system was already over titrated. This situation indicated a limited capacity to take up more $\mathrm{Fe}$ in the dissolved phase and a potential for greater scavenging rates as increases in dissolved $\mathrm{Fe}$ can only be achieved by processes that do not impact the ligand concentration. This is because as the soluble and colloidal ligand pools are saturated, and the inorganic solubility is also maximized, any more $\mathrm{Fe}$ that dissolves will lead to $\mathrm{Fe}$ being incorporated into existing colloidal aggregates or onto particles. However, after the second dust addition, the ligand concentration rose significantly in the dust seeded samples with values reaching $6.8 \mathrm{nmol} \mathrm{L}^{-1}$ at $\mathrm{t} 191(25)$, indicating a higher complexing capacity for Fe. At t239(73) and t311(145) the values decreased to $5.2-5.3 \mathrm{nmol} \mathrm{L}^{-1}$. 

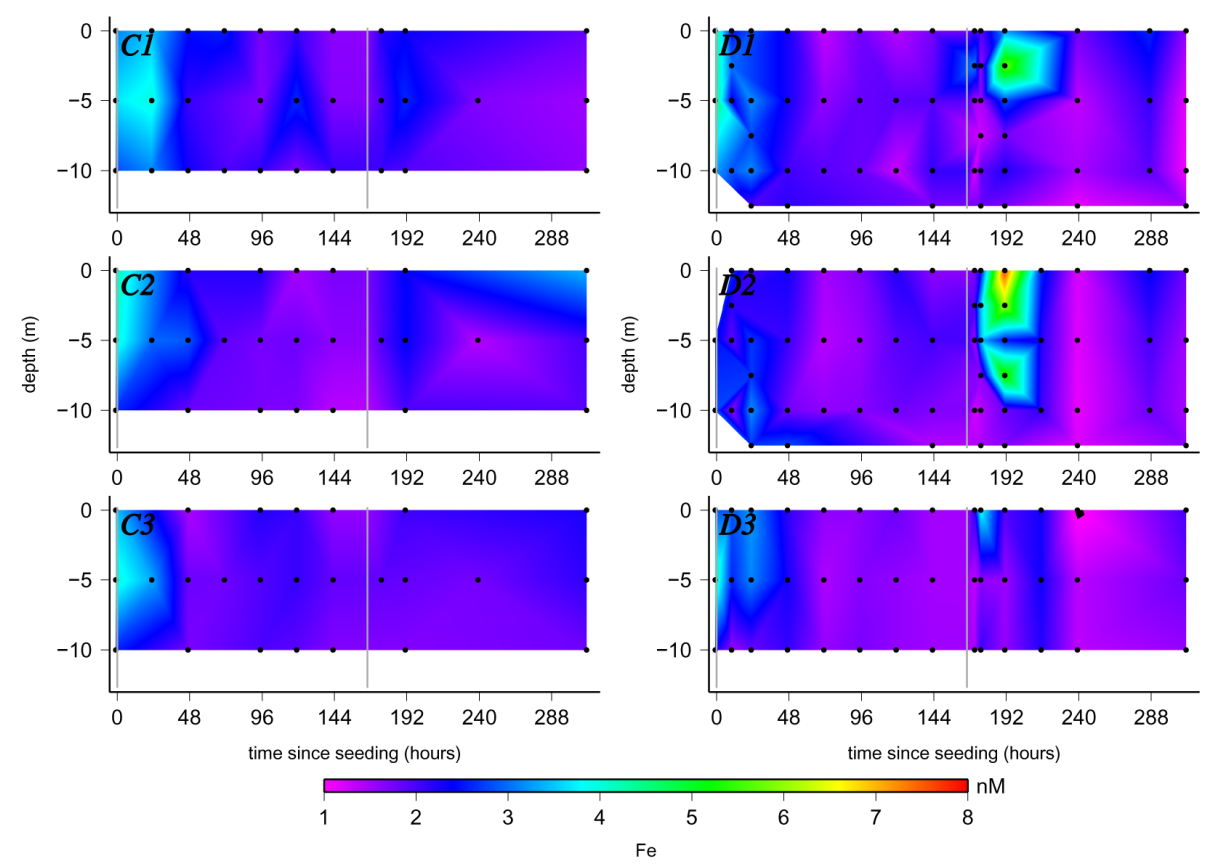

Fig. 2. Evolution of dissolved iron $(\mathrm{Fe})$ in the 6 mesocosms. This graph is plotted in the same way as Fig. 1.

\subsection{Evolution of dissolved aluminum (Al)}

The evolution of the concentrations of $\mathrm{Al}$ is displayed in Fig. 4. In all three control mesocosms, similar features were observed: the values decreased nearly linearly with time over the two weeks of the experiments, from $44 \mathrm{nmol} \mathrm{L}^{-1}$ to $38 \mathrm{nmol} \mathrm{L}^{-1}$. Values from outside the mesocosms were in the same range as those in the control mesocosms.

In the dust seeded mesocosms, directly after the first addition of dust at $\mathrm{t} 10$, the surface $\mathrm{Al}$ values increased to $54 \mathrm{nmol} \mathrm{L}^{-1}$ and the rest of the water column was also elevated $\left(48-50 \mathrm{nmol} \mathrm{L}^{-1}\right)$. The increase continued throughout the dust seeded mesocosms $\left(50-56 \mathrm{nmol} \mathrm{L}^{-1}\right)$, but most distinctive in the surface with concentrations up to 60 $63 \mathrm{nmol} \mathrm{L}^{-1}$ at $\mathrm{t} 47$. At the end of the first dust addition the $\mathrm{Al}$ concentrations were constant in all dust seeded mesocosms at approximately $55 \mathrm{nmol} \mathrm{L}^{-1}$.

After the second dust addition the $\mathrm{Al}$ concentrations increased by approximately $10 \mathrm{nmol} \mathrm{L}^{-1}(\mathrm{t} 215(49))$, for example up to $78 \mathrm{nmol} \mathrm{L}^{-1}$ in the surface in D1. At t239(73), the minimum value was $58 \mathrm{nmol} \mathrm{L}^{-1}$ and the maximum was reached with $66 \mathrm{nmol} \mathrm{L}^{-1}$ at several depths. At the end of the experiment, the values decreased to $53 \mathrm{nmol} \mathrm{L}^{-1}$ in D1 and $55-60 \mathrm{nmol} \mathrm{L}^{-1}$ in D2. In D3, a similar decrease with time could be observed, but the initial increase after the second addition was smaller compared to D1 and D2. At the end of the experiment (t311(145)), the values dropped to 42$46 \mathrm{nmol} \mathrm{L}^{-1}$.

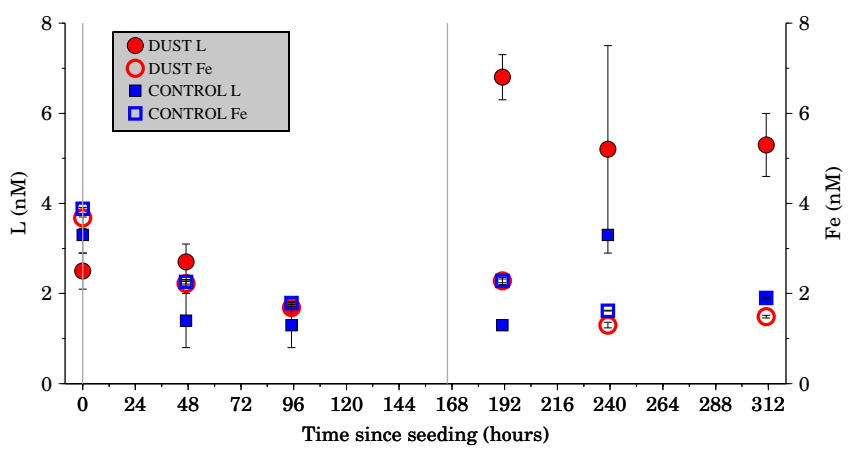

Fig. 3. Evolution of the arithmetical means of the iron binding ligand $(\mathrm{L})$ concentrations $\left(\mathrm{nmol} \mathrm{L}^{-1}\right)$ of the dust seeded mesocosms (red circles) and the control mesocosms (blue squares) at $5 \mathrm{~m}$ depth with time since the seeding. The evolution of the arithmetical means of the dissolved iron $(\mathrm{Fe})$ concentrations $\left(\mathrm{nmol} \mathrm{L}^{-1}\right)$ of the dust seeded mesocosms (red empty circles) and the control mesocosms (blue empty squares) at $5 \mathrm{~m}$ depth with time since the seeding.

\section{Discussion}

\subsection{Trace metal concentrations at the DUNE site}

All the total dissolved trace metal concentrations measured at the DUNE sampling site before the seeding are representative for the western Mediterranean basin (Boyle et al., 1985; Copin-Montegut et al., 1986; Kremling and Petersen, 1981; Morley et al., 1997; Sherrell and Boyle, 1988; Yoon et al., 1999). The average values of the total dissolved trace metal concentrations ( \pm standard deviation) before the addition of 

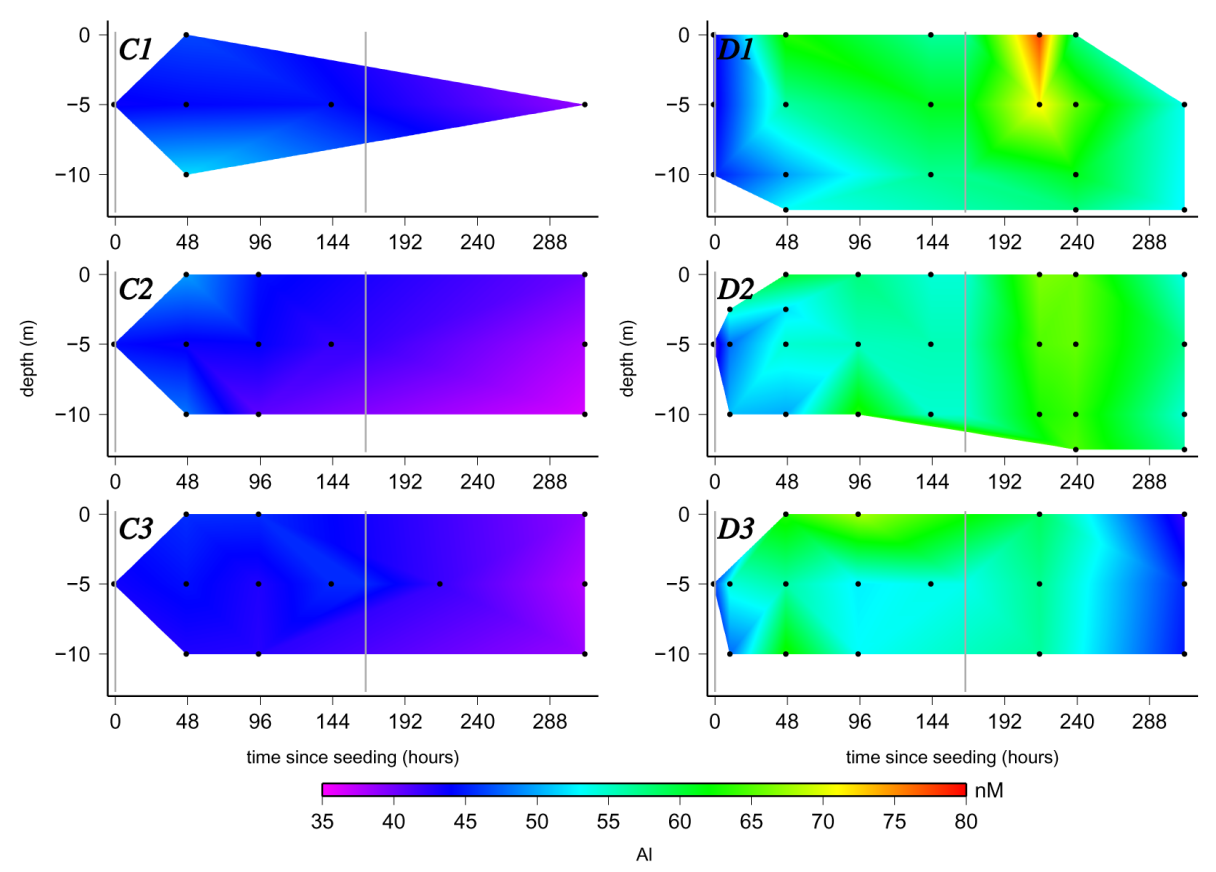

Fig. 4. The evolution of dissolved aluminum $(\mathrm{Al})$ in the 6 mesocosms. This graph is plotted in the same way as Fig. 1.

dust at $5 \mathrm{~m}$ depths at the DUNE site are given in Table 1 . For all the trace metals measured during DUNE-2, no significant differences could be observed between the initial values inside and outside the mesocosms. This indicates that the deployment protocol of the mesocosms, developed for the DUNE experiment (Guieu et al., 2010), does not contaminate the water column trapped inside for the trace element measured in this study. The concentrations are given as supplementary information and will not be discussed here any further. This is in agreement with the results obtained for $\mathrm{Fe}$ during DUNE-1 (Wagener et al., 2010).

Sherrell and Boyle (1988) report a limited set of data for total and dissolved $\mathrm{Fe}$ in the western Mediterranean. They found maximal values in the core of the Atlantic inflow jet to the Mediterranean in the Strait of Gibraltar of $53.0 \mathrm{nmol} \mathrm{kg}^{-1}$ total $\mathrm{Fe}$, with dissolved $\mathrm{Fe}$ making up only $30 \%$ of this value, indicating a high particulate load. Outside this plume of $\mathrm{Fe}$, total surface concentrations were around $5 \mathrm{nmol} \mathrm{kg}^{-1}$. The range of reported $\mathrm{Fe}$ concentrations is similar to those previously published for the western Mediterranean basin (Bonnet and Guieu, 2004; Sarthou and Jeandel, 2001; van den Berg, 1995). However, the initial Fe values in the mesocosms were in the higher range of reported data for the open waters of the western Mediterranean Sea, but similar coastal Fe concentrations were determined in the Bay of Villefranche at different times of the year (Bressac and Guieu, 2013). A study by Statham et al. (1985) of Mn concentrations in the Mediterranean also showed a surface enrichment up to $4.19 \mathrm{nmol} \mathrm{L}^{-1}$. Our observed Al concentrations are in the same range as previously reported surface values of about
$56 \mathrm{nmol} \mathrm{L}{ }^{-1}$ close to our study site off the coast of Corsica in 1977 (Caschetto and Wollast, 1979). Similar Al concentrations have also been observed in the western Mediterranean basin (Chou and Wollast, 1997; Hydes et al., 1988; van den Berg et al., 1994).

\subsection{Changes in trace metal inventories: dissolution and scavenging after the seeding}

The temperatures measured at four depths $(0,3,6$ and $10 \mathrm{~m})$ inside and outside the mesocosms are the only available physical continuously monitored parameters measured during the entire experiment. In Fig. 5a, the calculated temperature difference between the surface and the bottom of the mesocosm is plotted $(0-10 \mathrm{~m})$. The temperature difference between 0 and $10 \mathrm{~m}$ measured inside the mesocosm is therefore used as an indicator for mixing or thermal stratification in the mesocosm in order to discuss the changes in the inventories within the mesocosms. If there was little or no temperature difference between 0 and $10 \mathrm{~m}$, we interpreted this as an indication that the water column in the mesocosm was wellmixed. The more significant the temperature difference, the more likely the mesocosm was stratified. The main feature this proxy provides is that the course of the experiment can be separated into four periods. A relatively well-mixed mesocosm during the first four days (t96) of the experiment, followed by a stratification of the water column ( $\mathrm{t} 96-\mathrm{t} 180)$. The second addition of dust therefore occurred in a more stratified water column than the first one. After $\mathrm{t} 180$ the water column was mixed again until t 240 when a new stratification followed until the end of the experiment (Bressac et al., 2013). 
Table 1. Trace metal concentrations before the start of the experiment.

\begin{tabular}{|c|c|c|}
\hline & $\begin{array}{r}\text { Concentration } \\
\left(\text { nmol L } \mathrm{L}^{-1}\right) \\
\text { inside the } \\
\text { mesocosms }\end{array}$ & $\begin{array}{r}\text { Concentration } \\
\left(\text { nmol } \mathrm{L}^{-1}\right) \\
\text { outside the } \\
\text { mesocosms }\end{array}$ \\
\hline $\mathrm{Al}$ (FIA) & $43.8 \pm 1.4$ & $36.97^{\mathrm{a}}$ \\
\hline $\mathrm{Cd}(\text { ETAAS })^{\mathrm{e}}$ & $0.052 \pm 0.007$ & $0.05^{\mathrm{b}}$ \\
\hline Co (ETAAS) ${ }^{\mathrm{e}}$ & $0.099 \pm 0.007$ & $0.12^{\mathrm{b}}$ \\
\hline $\mathrm{Cu}(\text { ETAAS })^{\mathrm{e}}$ & $1.83 \pm 0.30$ & $1.42^{\mathrm{b}}$ \\
\hline $\mathrm{Fe}(\mathrm{FIA})$ & $3.78 \pm 0.67$ & 4.44 \\
\hline Mn (FIA) & $3.36 \pm 0.37$ & 3.50 \\
\hline $\mathrm{Ni}(\text { ETAAS) })^{\mathrm{e}}$ & $3.47 \pm 0.40$ & $3.34^{\mathrm{b}}$ \\
\hline $\mathrm{Pb}(\text { ETAAS })^{\mathrm{e}}$ & $0.104 \pm 0.017$ & $0.09^{\mathrm{b}}$ \\
\hline $\mathrm{Zn}(\text { ETAAS })^{\mathrm{e}}$ & $2.14 \pm 0.67$ & $1.01^{\mathrm{b}}$ \\
\hline
\end{tabular}

a This value was measured at $t 47$ after the start of the experiment.

${ }^{b}$ These values were measured at 1143 (-23) after the start of the experiment. ${ }^{\mathrm{c}}$ The errors presented with the mean values in this table correspond to the standard deviation $(1 \sigma)$ calculated on the values at $5 \mathrm{~m}$ in the 6 mesocosms directly after their deployment.

$\mathrm{d}$ We only had one reference point outside the mesocosms and therefore cannot give an error for the outside concentrations. ${ }^{\mathrm{e}}$ The graphite furnace atomic absorption method (ETAAS) for the dissolved trace metal concentrations (cadmium (Cd), cobalt (Co), copper $(\mathrm{Cu})$, nickel $(\mathrm{Ni})$, lead $(\mathrm{Pb})$ and zinc $(\mathrm{Zn}))$ is described in the supplementary information (Grasshoff et al., 1983; Danielsson et al., 1978).

Mesocosms are closed systems without lateral advection. Therefore, after the addition of dust, its effect on the cycling of trace metals can be completely assessed by using inventories over the water column of the mesocosms. For this reason the inventories were calculated for all three trace metals for each $5 \mathrm{~m}$ depth layer $(0-5 \mathrm{~m}$ and 5-10 $\mathrm{m})$. The final conical section of the mesocosms was neglected. The few missing values were interpolated if necessary by using the average values between two depths, or the values at the extremes (surface and bottom). The inventories for the $5 \mathrm{~m}$ increments were then added up as an inventory for the corresponding mesocosm at the corresponding time point $t x$. Figure 5 shows the evolution of the $\mathrm{Mn}(\mathrm{B}), \mathrm{Fe}(\mathrm{C})$ and $\mathrm{Al}(\mathrm{D})$ inventories as a function of the time since the addition of dust. The plotted inventories were calculated as arithmetical means for the control and the dust seeded mesocosms. For all three elements ( $\mathrm{Fe}, \mathrm{Al}$ and $\mathrm{Mn}$ ), the inventories in the dust seeded and control mesocosms were equivalent before the start of the experiment. The Mn and Al dust seeded inventories were always higher than the $\mathrm{Mn}$ and $\mathrm{Al}$ control inventories, which remained constant or decreased slightly throughout the whole experiment, whereas the inventories in the dust seeded mesocosms showed a remarkable increase during $\mathrm{t} 47-\mathrm{t} 73$ after both the seedings, followed by a decrease in the inventories in the following days. Fe inventories showed a different trend with a distinct quicker and stronger decrease in the dust seeded compared to the control mesocosms after the first dust seeding. This decrease until t73 was
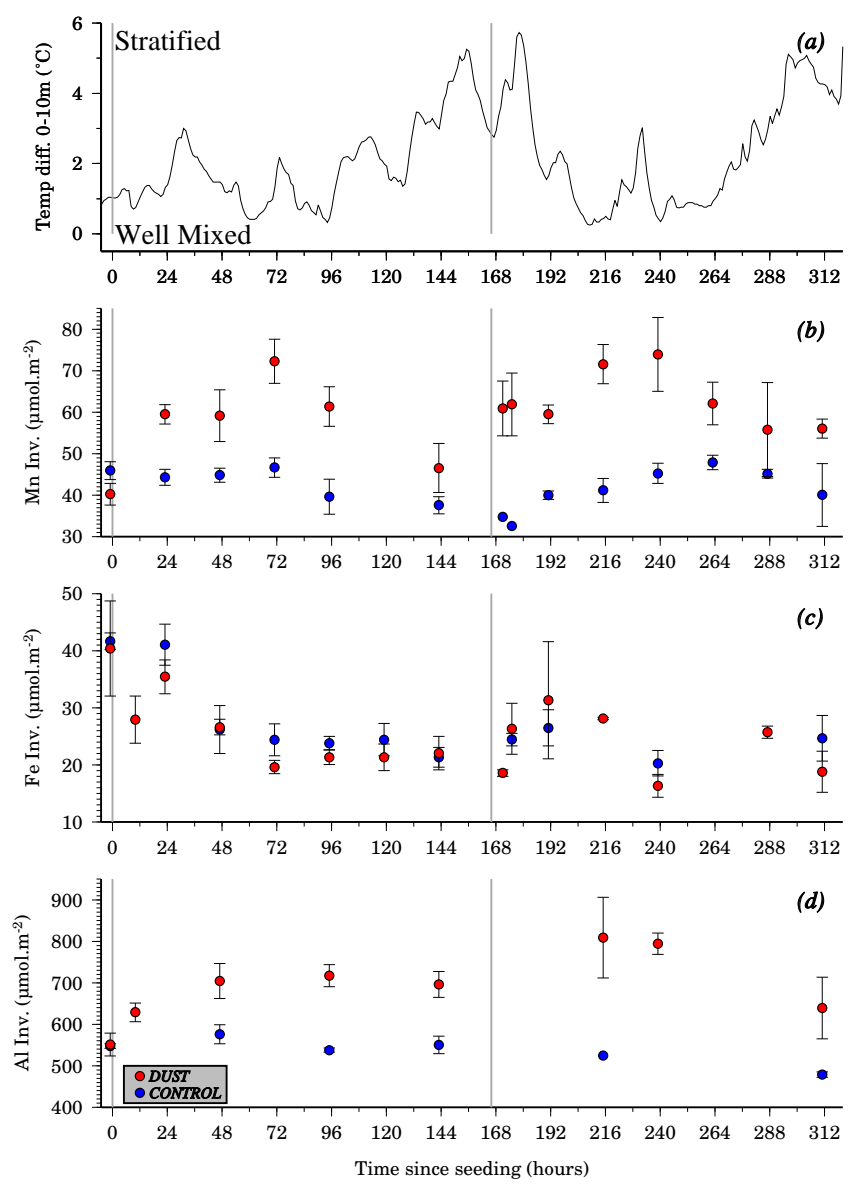

Fig. 5. Evolution of the temperature difference $(0-10 \mathrm{~m})$ (a) and the arithmetical means of the dissolved trace metal inventories $\left(\mu \mathrm{mol} \mathrm{m}{ }^{-2}\right)(\mathrm{Mn}(\mathbf{b}), \mathrm{Fe}$ (c) and $\mathrm{Al}(\mathbf{d})$ from top to bottom) of the dust seeded mesocosms (red circles) and the control mesocosms (blue circles).

followed by constant inventories during the rest of the experiment. Only a very transient, but strong increase could be observed in the dust seeded mesocosms one day after the second addition of dust (t191(25)).

Based on these inventory calculations, changes are discussed (1) in terms of absolute inventories based on estimations of trace metal solubilities from dust particles and (2) in terms of relative changes of the inventories based on estimations of dissolution and loss rates of the three elements.

\subsubsection{Estimation of dissolution during the mesocosm experiment}

The fractional solubility (FracSol \%) of an element from the dissolution of dust particles in seawater (Baker and Croot, 2010) is typically expressed as the percentage of the soluble element compared to the total element in the dust particle. This percentage allows an estimation of the impact of the atmospheric particle flux on the dissolved (and bioavailable) 
stock in the ocean (Landing and Paytan, 2010). In recent years, two major experimental protocols have been used to assess the solubility of collected dust particles in seawater: flow through protocols (e.g. Buck et al., 2006) and batch experiments (e.g. Bonnet and Guieu, 2004). As discussed in Wagener et al. (2010), mesocosms allow us to estimate solubility from dust particles in a somewhat in situ way: the settling of the particles through the water column and interactions with naturally occurring particles are both integrated in this approach. However, two main limitations are inherent to this approach: (1) the dust addition is based on artificially produced dust particles which might not completely reproduce natural particles and (2) the results obtained are only relevant for the area where the mesocosms have been deployed. For a given element at a given time, the fractional solubility is the ratio between the increase in the dissolved metal concentrations ( $[M])$ due to dust dissolution in seawater (in this case integrated over the entire mesocosm) and the total amount of this element introduced with the dust particles $\left(\Sigma M_{\text {Dust }}\right)-$ as indicated below.

Here, the solubility of each element from the added dust is estimated at the time point $(t)$ when the inventory of this dissolved element in the mesocosms is at its maximum after the dust addition. In the present work we utilized Eq. (1) (below) for the phase of the first dust addition, in which the amount of the dissolved element introduced by the dust is estimated as the difference between the inventories in the dust seeded mesocosms (DM) and the control mesocosms (CM). The total amount of the element introduced by dust is estimated from the amount of dust introduced to the mesocosm and its elemental composition (K. Desboeufs, personal communication, 2013). It is assumed here that no dust was lost when it was sprayed at the surface of the mesocosm (see Sect. 2.1.):

$\operatorname{FracSol}(\%)=\frac{\max \left\{A\left(\left|\int_{z}^{0}[M]_{\mathrm{DM}} \partial z\right|_{t}-\left|\int_{z}^{0}[M]_{\mathrm{CM}} \partial z\right|\right)\right\}}{\Sigma M_{\text {Dust }}}$

\section{Case 1: first addition}

Where $A$ is the surface area of the mesocosm and assuming it is a perfect cylinder, $t$ represents the time since the first dust addition.

It is important to notice that in the case of this experiment, using the difference of the inventories between dust seeded and control mesocosms to estimate the dissolved amount allows us to take into consideration the ongoing changes in the dissolved concentrations observed in the control mesocosms during the experiment. The inventory changes for the dissolved metals in the control mesocosms are independent of the added dust and must therefore not be taken into account in the solubility calculation. This is an important difference with classical abiotic batch protocols where the amount of dissolved element is estimated from the difference in concen- tration before and after the dust addition. However, in order to estimate FracSol\% induced by the second dust addition only, the amount of the dissolved element introduced needs to be calculated by comparison with the inventories in the dust mesocosms (DM) immediately prior to the second seeding (t143(-23)) and we therefore utilized Eq. (2) for the second seeding. An estimation of FracSol \% based on Eq. (1) for the second dust addition would cumulate the effect of the two additions. Values of fractional solubility are reported in Table 2.

$\operatorname{FracSol}(\%)=\frac{\max \left\{A\left(\left|\int_{z}^{0}[M]_{\mathrm{DM}} \partial z\right|_{t}-\left|\int_{z}^{0}[M]_{\mathrm{DM}} \partial z\right|_{\mathrm{t} 143}\right)\right\}}{\Sigma M_{\text {Dust }}}$

\section{Case 2: second addition}

The fractional solubility for $\mathrm{Al}$ after the first and second dust addition was, respectively, $1.44 \pm 0.19 \%$ and $0.91 \pm 0.83 \%$. There is no significant difference between these additions and the high variability for the second addition, which is due to the much lower values for $\mathrm{Al}$ observed in D3. In this mesocosm, significantly higher concentrations of bacteria were also observed, indicating that some other processes were occurring in this mesocosm compared to D1 and D2. Our data are consistent with results from Measures et al. (2010) who measured fractional Al solubilities of 0.087 to $14.3 \%$ (average $4.6 \%$ ) in seawater with Hawaiian aerosol samples. For Saharan dust, fractional Al solubilities of 1.9$5.5 \%$ in pH 4.7 solutions have been published by Baker et al. (2006), so our data are consistent with these results given the higher $\mathrm{pH}$ in seawater. For $\mathrm{Mn}$, the fractional solubilities are higher, but after both dust additions in the same order of magnitude with values of $41 \pm 9$ and $27 \pm 19 \%$. Recently, Mendez et al. (2010) reported values of 12 to $14 \%$ for Saharan dust in laboratory experiments with seawater, while Baker et al. (2006) reported values of $50-64 \%$ in pH 4.7 solutions. Earlier, Guieu et al. (1994) have shown fractional Mn solubilities of $30-35 \%$ in $\mathrm{pH} 7$ solutions. Values obtained with the "mesocosm" method are thus comparable to other experimental setups.

During the DUNE-1 experiment no dissolution from the dust particles was observed for $\mathrm{Fe}$ and therefore no value for the fractional solubility of Fe was obtainable (Wagener et al., 2010). Here, during DUNE-2, the same result was obtained after the first seeding, but a fractional solubility of $0.12 \pm 0.03 \%$ was estimated after the second addition of dust. The reasons for this change in the amount of the dissolved element introduced by the dust and the induced fractional solubility are discussed in Sect. 4.4. Literature values for fractional $\mathrm{Fe}$ solubility range over more than three orders of magnitude (Baker and Croot, 2010; Sholkovitz et al., 2012) with large differences depending on atmospheric and 
Table 2. Estimation of the elemental relative dissolution of dust in seawater.

\begin{tabular}{|c|c|c|c|c|}
\hline & & $\mathrm{Mn}$ & $\mathrm{Fe}$ & $\mathrm{Al}$ \\
\hline & Elemental dust addition $\left(\mu \mathrm{mol} \mathrm{m}{ }^{-2}\right)^{\mathrm{a}}$ & 63.7 & 4136 & 15271 \\
\hline \multirow{3}{*}{$\begin{array}{l}\text { First } \\
\text { seeding }\end{array}$} & $\begin{array}{l}\text { Difference of inventories } \\
\text { Average maximum in the dust seeded mesocosms minus average } \\
\text { control mesocosms }\left(\mu \mathrm{mol} \mathrm{m} \mathrm{m}^{-2}\right)^{\mathrm{b}}\end{array}$ & $25.6 \pm 5.8$ & NA & $177 \pm 24$ \\
\hline & Dissolution $(\%)^{\mathrm{c}}$ & $40 \pm 9$ & NA & $1.2 \pm 0.2$ \\
\hline & $\begin{array}{l}\text { Time when dust seeded mesocosms inventories reached their max- } \\
\text { ima (h) }\end{array}$ & $\mathrm{t} 71$ & NA & $\mathrm{t} 47$ \\
\hline \multirow{3}{*}{$\begin{array}{l}\text { Second } \\
\text { seeding }\end{array}$} & $\begin{array}{l}\text { Difference of inventories } \\
\text { Average maximum in the dust seeded mesocosms minus dust seeded } \\
\left.\text { mesocosms prior to second addition }(\mu \mathrm{mol} \mathrm{m})^{-2}\right)^{b}\end{array}$ & $17.1 \pm 11.8^{\mathrm{d}}$ & $4.9 \pm 1.2$ & $112 \pm 103^{d}$ \\
\hline & Dissolution $(\%)^{\mathrm{c}}$ & $27 \pm 19^{d}$ & $0.12 \pm 0.03$ & $0.73 \pm 0.67^{d}$ \\
\hline & $\begin{array}{l}\text { Time when dust seeded mesocosms inventories reached their max- } \\
\text { ima (h) }\end{array}$ & t239 & $\mathrm{t} 191$ & $\mathrm{t} 215$ \\
\hline
\end{tabular}

${ }^{a}$ Estimation based on the addition of $10 \mathrm{~g} \mathrm{~m}^{-2}$ of dust with an elemental composition of $\mathrm{Mn}=0.0342 \%, \mathrm{Fe}=2.26 \%$ and $\mathrm{Al}=3.32 \%$ (Desboeufs, personal communication, 2013). ${ }^{\mathrm{b}}$ Estimated with mean values for control and dust seeded mesocosms. ${ }^{\mathrm{c}}$ Estimated as the ratio between the difference of inventories and the amount of element added with dust. ${ }^{\mathrm{d}}$ High variability here related to differences in D3, also seen in bacterial numbers and phytoplankton abundance.

marine processes as well as on the experimental design used. In summary, based on a much more realistic protocol than the commonly used laboratory protocols, the fractional solubility of $\mathrm{Mn}$ and the fractional solubility of $\mathrm{Al}$ in dust are in the range of previously published values. This overall gives more confidence in consensus ranges for fractional $\mathrm{Al}$ and $\mathrm{Mn}$ solubility from dust. For $\mathrm{Fe}$, the complex processes that control the fractional solubility are clearly shown here, and indicate that the use of a single absolute value for the fractional solubility of $\mathrm{Fe}$ is not realistic.

\subsubsection{Dissolution and loss rates}

The rates of the decreases or increases in the inventories were quantified by estimating loss and dissolution rates. These estimated rates for $\mathrm{Mn}, \mathrm{Al}$ and $\mathrm{Fe}$ are reported in Table 3.

An overall trend, observed for the three dissolved trace metals, was a general decrease in the inventories in the control mesocosms with low loss rates. This could correspond to scavenging onto particles, which is a common physicalchemical process occurring in the ocean for trace metals (Turekian, 1977). The loss rate was well defined for Al, which is not known to have a bioactive role, whereas some variations over the general decreasing trend were observed for Fe and Mn. This might be due to changes in biological utilization in response to the changes in stratification in the mesocosms.

In the dust seeded mesocosms, the inventories of $\mathrm{Mn}$ and $\mathrm{Al}$ increased with apparent dissolution rates which were quite similar for both dust additions. It is interesting to note that, even if the dust additions occurred under different stratification conditions (Fig. 5a), the increase in the inventories and the dissolution rates were the same when integrated over the entire mesocosm. However, Fig. 1 clearly shows that the increase in Mn concentrations was occurring throughout the whole water column for the first compared to the second seeding, in which the increase was concentrated in the first few meters of the mesocosms. This implies that the overall rate of dissolution and fractional solubility was apparently not affected by the vertical mixing of the water column, but that mixing diluted the maximal concentration observed for the dissolved elements. This has important implications, illustrating that the sampling resolution can impact the assessment of the influence of dust addition. For example, the determination of vertical gradients, using finer spatial sampling resolution within the mesocosms, helps better define the processes occurring.

The loss rates of $\mathrm{Al}$ and $\mathrm{Mn}$ behaved differently. $\mathrm{Mn}$ showed quite equivalent loss rates for the first and the second seeding, whereas the Al loss rate was approximately one order of magnitude higher after the second seeding $\left(-1.9 \mu \mathrm{mol} \mathrm{m}^{-2} \mathrm{~d}^{-1}\right)$ in comparison to after the first one $\left(-0.07 \mu \mathrm{mol} \mathrm{m}{ }^{-2} \mathrm{~d}^{-1}\right)$. Scavenging of $\mathrm{Al}$ is sensitive to the amount of biogenic particles in seawater (Moran and Moore, 1988). During DUNE-2, an increase of chlorophyll $a$ in the dust seeded mesocosms is reported by Giovagnetti et al. (2012), suggesting an increase of biomass, which could explain the observed significant change in the loss rates for Al. Correlations of leachable $\mathrm{Al}$ and chlorophyll $a$ were also previously observed by Moran and Moore (1988), suggesting 
Table 3. Mn, Fe and Al dissolution and loss rates in $\mu \mathrm{mol} \mathrm{m} \mathrm{m}^{-2} \mathrm{~d}^{-1}( \pm 1 \sigma)$. They were calculated as the increase/decline of each metal in each of the dust seeded mesocosms by applying a linear regression to the inventory as a function of time. For the dissolution rates the calculation was started at the point before each of the seedings until the point in time when the concentration reached its maximum. For the loss rates the calculation was started at the point after each of the seedings when the concentration was the highest.

\begin{tabular}{|c|c|c|c|c|c|}
\hline $\begin{array}{l}\text { dissolved } \\
\text { trace } \\
\text { metal }\end{array}$ & seeding & $\begin{array}{r}\text { Dissolution } \\
\text { rates } \\
\left(\mu \mathrm{mol} \mathrm{m}{ }^{-2} \mathrm{~d}^{-1}\right)\end{array}$ & $\begin{array}{r}\text { Time intervals } \\
\text { (h) used }\end{array}$ & $\begin{array}{r}\text { loss rate } \\
{\left[\mu \mathrm{mol} \mathrm{m}{ }^{-2} \mathrm{~d}^{-1}\right]}\end{array}$ & $\begin{array}{r}\text { Time intervals } \\
\text { (h) used }\end{array}$ \\
\hline Mn & 1 & $0.43 \pm 0.09$ & $\mathrm{t} 0-\mathrm{t} 71$ & $-0.35 \pm 0.04$ & $\mathrm{t} 71-\mathrm{t} 143$ \\
\hline $\mathrm{Mn}$ & $\begin{array}{l}2 \\
\text { Control }\end{array}$ & $0.27 \pm 0.05$ & $\mathrm{t} 143(-23)-\mathrm{t} 239(73)$ & $\begin{array}{r}-0.25 \pm 0.08 \\
-0.006 \pm 0.013\end{array}$ & $\begin{array}{r}\mathrm{t} 239(73)-\mathrm{t} 311(145) \\
\mathrm{t} 0-\mathrm{t} 311(145)\end{array}$ \\
\hline $\mathrm{Fe}$ & 1 & NA & NA & NA & NA \\
\hline $\mathrm{Fe}$ & 2 & $0.67 \pm 0.15$ & t171(5)-t191(25) & NA & NA \\
\hline & Control & NA & NA & $-0.01 \pm 0.01$ & $\mathrm{t} 47-\mathrm{t} 311(145)$ \\
\hline $\mathrm{Al}$ & 1 & $2.8 \pm 1.3$ & $\mathrm{t} 0-\mathrm{t} 47$ & $-0.07 \pm 0.17$ & $\mathrm{t} 47-\mathrm{t} 143$ \\
\hline $\mathrm{Al}$ & $\begin{array}{l}2 \\
\text { Control }\end{array}$ & 1,1 & $\mathrm{t} 143(-23)-\mathrm{t} 215(49)$ & $\begin{array}{r}-1.9 \pm 0.3 \\
-0.24 \pm 0.07\end{array}$ & $\begin{array}{r}\mathrm{t} 215(49)-\mathrm{t} 311(145) \\
\mathrm{t} 0-\mathrm{t} 311(145)\end{array}$ \\
\hline
\end{tabular}

a link between scavenging of $\mathrm{Al}$ and chlorophyll $a$. During DUNE-2 we also observed a similar correlation (Fig. 6) using the chlorophyll $a$ inventory (Giovagnetti et al., 2012). Figure 6 shows an increase of the chlorophyll $a$ inventory related to an increase of the $\mathrm{Al}$ loss rate. Previous studies in the vicinity of Corsica have shown that $\mathrm{Al}$ is strongly covariant with silicate (Mackenzie et al., 1978), suggesting removal of dissolved $\mathrm{Al}$ by incorporation in diatoms with subsequent remineralization at depth. In the present case, however, non-siliceous pico-plankton (Synechococcus and Prochlorococcus) and nano-plankton (Haptophytes and Chlorophytes) showed the major response to the dust additions, particularly after the second addition (Giovagnetti et al., 2012). Therefore, it appears that the loss of dissolved $\mathrm{Al}$ was related to adsorption into organic matter on these cells and not incorporation into biogenic silica. Stratification after the second dust addition may have accentuated this Al removal at this time, as higher concentrations of cyanobacteria and haptophytes were also observed at this time in the surface waters (Giovagnetti et al., 2012).

In the case of $\mathrm{Mn}$, there was no appreciable difference in the loss rate after the first and second additions of dust, suggesting that the loss of Mn was not affected by uptake or adsorption into phytoplankton. Scavenging of Mn by particles requires the oxidation of $\mathrm{Mn}$ (II) prior to particle loss, as $\mathrm{Mn}$ (II) is only weakly complexed or adsorbed to particles (Yeats and Strain, 1990; Sunda and Huntsman, 1987). Abiotic oxidation of $\mathrm{Mn}$ (II) is normally considered to be too slow to account for the adsorbed loss rates and instead it is believed that bacterial oxidation is the major pathway in the ocean (Morgan, 2005; von Langen et al., 1997). During this experiment bacterial numbers were relatively constant throughout the experiment in all mesocosms, suggesting that the Mn oxidation rate was relatively constant (Pulido-Villena et al., 2013). The dissolved Mn loss rates observed here are equivalent to $6.5-10.8 \% \mathrm{~d}^{-1}$ of the dissolved
Mn pool, which is significantly above the range of rates (0.2$1.5 \% \mathrm{~d}^{-1}$ ) observed in oligotrophic regions (Moffett, 1997) but similar to that seen in coastal regions (Sunda and Huntsman, 1987). Thus, the turnover time of the Mn pool was about 10 to 16 days in the dust amended mesocosms. The slower turnover of $\mathrm{Mn}$ in the control mesocosms presumably indicates that $\mathrm{Mn}$ oxidation by bacteria may have been limited by another substrate, in this case presumably suitable organic carbon sources. Our rates are also integrated over the whole day and it is also likely that a diel cycle in $\mathrm{Mn}$ oxidation was occurring due to photo-reduction of $\mathrm{MnO}_{2}$ via reaction with humics or photo-produced $\mathrm{H}_{2} \mathrm{O}_{2}$, and potential photo-inhibition of Mn oxidizing bacteria, as it has been observed in coastal waters and the Sargasso Sea (Sunda and Huntsman, 1988, 1990). Thus, it is likely that Mn oxidation rates were maximal at night.

Changes in the Fe inventories were complex with regard to the dust addition. In the first day ( $\mathrm{t} 0-\mathrm{t} 23)$, the loss rate in the dust seeded mesocosms was $-45.5 \mu \mathrm{mol} \mathrm{m} \mathrm{m}^{-2} \mathrm{~d}^{-1}$, whereas it was slightly positive in that time frame in the control mesocosms. The control inventories only started to decrease after $\mathrm{t} 23$. The loss rate in the dust seeded mesocosms on the first day was comparable to the one reported for DUNE-1. This might demonstrate an assimilable scavenging onto dust particles, which had been demonstrated for DUNE-1 (Wagener et al., 2010). Until t72, an overall sharp decrease in the loss rates was observed in both the control and the dust seeded mesocosms. This decrease had not been observed in the control mesocosms during DUNE-1. A plausible reason for this decrease could be adsorption onto the mesocosms' plastic walls, by which the walls were not in equilibrium with the seawater initially during DUNE-2. It has been demonstrated in bottle experiments (e.g. Fischer et al., 2007), that this could represent up to $50 \%$ of $\mathrm{Fe}$ in bottles. But, as the surface to volume ratio is much lower for large mesocosms, 
wall adsorption cannot explain entirely the Fe loss in the control mesocosms.

After the second addition, a transient dissolution of Fe was observed within the first day (t166(0)-t191(25)) with a dissolution rate of $0.67 \pm 0.15 \mu \mathrm{mol} \mathrm{m} \mathrm{m}^{-2} \mathrm{~d}^{-1}$, which was higher than the loss rate observed after the first seeding. In the earlier DUNE-1 experiment, Wagener et al. (2010) estimated a maximal biological uptake of $\mathrm{Fe}$ in the mesocosms of 0.5 to $1.0 \mu \mathrm{mol} \mathrm{m} \mathrm{m}^{-2} \mathrm{~d}^{-1}$ for the productive conditions encountered during this experiment. During DUNE-2, the productive conditions were in the same order of magnitude compared to DUNE-1 in terms of autotrophic and heterotrophic organisms. We therefore postulate that dissolution from dust particles could therefore sustain biological activity in terms of relieving any potential $\mathrm{Fe}$ limitation. This transient dissolution observed after the second addition corresponds with a significant increase in Fe binding ligands in the dust seeded mesocosms in comparison to the control mesocosms (Fig. 3). The ligand concentration increased about $5 \mathrm{nmol} \mathrm{L}^{-1}$ between the mean concentrations measured at $\mathrm{t} 95$ before the second dust addition and the mean concentrations measured at t191(25) after the second dust addition. This increase of the Fe binding capacity is compatible with the transient increase in $\mathrm{Fe}$ concentration, with values up to $7.64 \mathrm{nmol} \mathrm{L}^{-1}$ observed at t191(25) in the surface of D2. In any case, the observed excess of ligands would have helped to maintain $\mathrm{Fe}$ in solution and drive the observed transient dissolution on addition of the dust. A similar occurrence was also seen during SOIREE, Southern Ocean Fe enrichment, where Fe binding ligand concentrations increased after successive $\mathrm{Fe}$ additions, leading to an increase in the retention of $\mathrm{Fe}$ in the water column (Croot et al., 2001).

\subsection{Insights into the time scales and possible mechanisms of dissolution and scavenging processes during a dust event}

Our unique dataset allows a first order look at the scavenging mechanisms following atmospheric deposition events. Previous work on this has been done over much larger temporal (week to month) and vertical (hundreds of meters) scales through the use of sediment traps (Brust et al., 2011; Brust and Waniek, 2010). The DUNE-2 experiment is unique in the sense that optical measurements in the water column were made simultaneously, allowing an assessment of the particle residence time. This particulate export was controlled partly by the formation of organic-mineral aggregates (Bressac et al., 2012). The mass of material exported into the sediment traps (collected every $24 \mathrm{~h}$ ) was the highest at $\mathrm{t} 48$. At the end of the first seeding experiment, the optical parameters were homogenous from 0 to $10 \mathrm{~m}$ depth, but still slightly higher than before the first addition of dust (Bressac et al., 2012). During the second part of the DUNE-2 experiment, optical measurements were also performed in order to follow the particle dynamics (Bressac et al., 2013). These optical

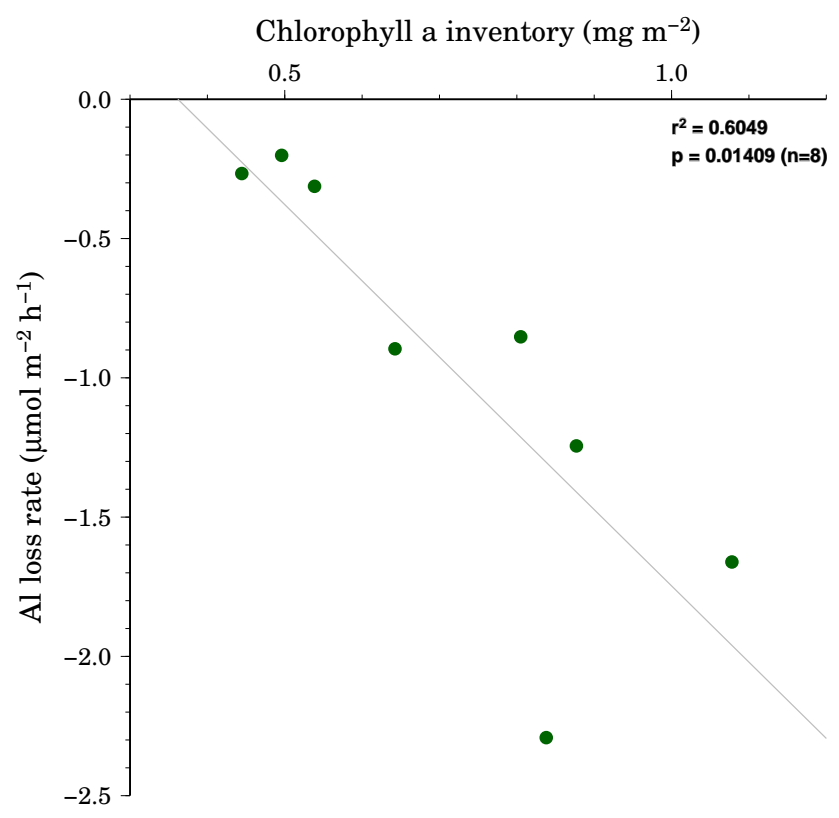

Fig. 6. Correlation of Al loss rate vs. the chlorophyll $a$ inventory.

measurements revealed an accumulation of particles in the upper $2.5 \mathrm{~m}$ layer directly following the second dust addition, likely due to the stratification of the water column (Fig. 5a). This particle maximum was apparently partly due to increases in phytoplankton abundance triggered by the second dust addition (Giovagnetti et al., 2012). This longer residence time of particles in the subsurface could explain the high $\mathrm{Fe}$ dissolution observed after the second addition of dust. However, the mass of material exported into the sediment traps was the highest at 1 191(25). Indeed, the mixing of the water column occurred between t179(13) (maximum of the temperature difference $(0-10 \mathrm{~m})$ ) and t215(49) (Fig. 5a). Simultaneously, a sudden decrease of the beam attenuation in the subsurface was observed between t176(8) and t191(25), revealing the activation of the particulate export (Bressac et al., 2013). The optical measurements indicate that part of the Saharan dust was rapidly lost from the mixed layer (estimated sinking rates $\sim 24-86 \mathrm{~m} \mathrm{~d}^{-1}$ ). As reported above, after the first seeding with dust, part of the Saharan dust pool was rapidly exported. The physical characteristics of the water column differed widely between both dust addition experiments. This difference in physical conditions, especially marked during the first hours after the seedings, likely impacted the particulate export dynamics and could partly explain the differences observed in the kinetic dissolution between the two additions of dust. These findings are important in the present context as they represent the removal of particulates and the adsorbed or scavenged metals they contain. Our observations are consistent with field studies from the Atlantic Ocean which have shown that the residence time of Fe in surface waters is strongly influenced by Saharan 
dust deposition (Croot et al., 2004), while that of Mn and $\mathrm{Al}$ are much less so (Jickells et al., 1994; Jickells, 1999). In the case of $\mathrm{Fe}$ in the surface waters, Croot et al. (2004) showed that the fractional mean residence time was shortened with increasing Saharan dust fluxes. Earlier laboratory studies have shown that scavenging and export are controlled by the formation of organic-mineral aggregates (Balistrieri et al., 1981; Hunter, 1983), with scavenging related to particle concentration (Honeyman et al., 1988). For particle reactive elements, e.g. Fe, the transfer of colloidal to particulate phases (colloidal pumping) is also important (Honeyman and Santschi, 1991). Combining the optical data with the dissolved trace metal data suggests that the larger dust particles sunk out quickly (Bressac et al., 2013) but played a small role in scavenging both $\mathrm{Mn}$ and $\mathrm{Al}$ from the water column, as release processes dominated at that time. Thus, scavenging by smaller particles (dust and phytoplankton/bacteria) appears to be the more important removal term over the duration of the experiment. In particular, the production of organic material by bacteria and phytoplankton would lead to increased formation of organic-mineral aggregates and lead to increased scavenging.

\subsection{Effect of two successive dust additions on the biogeochemistry of trace metals}

During the DUNE-1-P experiment, batch reactor dissolution experiments of dust performed with filtered seawater collected in the dust seeded and the control mesocosms have shown that the solubility of $\mathrm{Fe}$ increased significantly in the dust seeded mesocosms $7 \mathrm{~d}$ after the addition of dust (Wagener et al., 2010). A probable mechanism could be the production of specific $\mathrm{Fe}$ binding ligands by heterotrophic bacteria in the dust seeded mesocosms in response to a change in the bioavailability of $\mathrm{Fe}$ after the settling of particles. This hypothesis was supported by observations of changes in the diversity of the bacterial community attached to the dust particles (Laghdass et al., 2011).

Here during DUNE-2, this hypothesis was completely verified for Fe where a comparable response to the first addition of dust was observed with an increased scavenging of $\mathrm{Fe}$, whereas after the second addition of dust, dissolution of Fe from the dust particles was observed. No additional dust dissolution batch reactor experiments were performed during DUNE-2, but Fe binding ligand measurements by ligand competition and cathodic stripping voltammetry showed a significant increase of $\mathrm{Fe}$ binding ligands at t191(25), in complete accordance with the increase in Fe solubility observed for DUNE-1. As mentioned earlier, this increase in $\mathrm{Fe}$ binding ligands can explain the transient increase in $\mathrm{Fe}$ inventory. However, it is interesting to note that the increase of Fe concentration by the second addition of dust was only very limited in time $(24 \mathrm{~h})$, whereas the ligand concentration in the dust seeded mesocosms remained high until the end of the experiment. The Fe inventory after the second dust ad- dition rapidly decreased to the pre-addition values when a massive export of lithogenic particles was observed with the release of the stratification of the water column (Fig. 5a).We observed different behavior for $\mathrm{Mn}$ and $\mathrm{Al}$ in comparison to Fe and this can be explained by differences in their speciation in seawater. Whereas the solubility of $\mathrm{Mn}$ and $\mathrm{Al}$ is controlled solely by inorganic species, the solubility of soluble and colloidal $\mathrm{Fe}$ is controlled by organic complexes (Gledhill and Buck, 2012). Indeed, opposing effects were observed for $\mathrm{Al}$ and $\mathrm{Fe}$. The consecutive additions of dust did not impact the dissolution of Al but did impact the loss rate through the increase of scavenging onto biogenic particles induced by biomass increase subsequent to the first dust addition. However, this mechanism was not observed for Mn, which is certainly subject to more complex redox and photochemical processes (Sunda and Huntsman, 1987, 1988). Overall, this demonstrates that the biogeochemistry of the surface ocean responds in a nonlinear way to the atmospheric flux of dust to the seawater. The frequency of the depositions needs to be taken into account because it will condition the impact of the deposited particles. This has important consequences on the time scales that have to be studied in order to obtain a realistic picture of the impact of dust deposition.

\section{Supplementary material related to this article is available online at: http://www.biogeosciences.net/10/ 2583/2013/bg-10-2583-2013-supplement.zip.}

Acknowledgements. This study was financially supported by ANRDUNE under the contract ANR-07-BLAN-0126-01. Funding for the participation of $\mathrm{K}$. Wuttig and support of the work performed during DUNE-2 were provided by grants from the DFG to P. L. Croot (CR145/15-1 and CR145/17-1). The financial support by the BMBF Verbundprojekt SOPRAN (FKZ 03F0462A and 03F0611A), which is a German contribution to SOLAS (Surface Ocean - Lower Atmosphere Studies), is also gratefully acknowledged. T. Wagener was supported by a Marie Curie IEF (Grant agreement No. PIEF-GA-2009-236694, DAPOP). M. Bressac acknowledges a PhD grant provided by the ACRI-ST company and the French National Association for Research and Technology (ANRT). J. M. Dominici and collaborators of the Réserve naturelle de Scandola, Parc naturel régional de Corse are gratefully acknowledged for their cooperation and help in performing the experiment in the Bay of Elbo. We thank all of the participants of the DUNE-2 experiment for their involvement. Special thanks are also due to F. Malien and M. Lohmann (GEOMAR) for their nutrient laboratory work on very short notice and to Sandrine Chifflet (MIO) for all her Fe binding ligand measurements. We would like to acknowledge the editor and four anonymous reviewers for improving this paper.

The service charges for this open access publication have been covered by a Research Centre of the Helmholtz Association.

Edited by: E. Marañón 


\section{References}

Aguilar-Islas, A. M., Resing, J. A., and Bruland, K. W.: Catalytically enhanced spectrophotometric determination of manganese in seawater by flow-injection analysis with a commercially available resin for on-line preconcentration, Limnol. Oceanogr. Meth., 4, 105-113, doi:10.4319/lom.2006.4.105, 2006.

Baker, A. R. and Croot, P. L.: Atmospheric and marine controls on aerosol iron solubility in seawater, Mar. Chem., 120, 4-13, doi:10.1016/j.marchem.2008.09.003, 2010.

Baker, A. R. and Jickells, T. D.: Mineral particle size as a control on aerosol iron solubility, Geophys. Res. Lett., 33, L17608, doi:10.1029/2006g1026557, 2006.

Baker, A. R., Jickells, T. D., Witt, M., and Linge, K. L.: Trends in the solubility of iron, aluminium, manganese and phosphorus in aerosol collected over the atlantic ocean, Mar. Chem., 98, 43-58, doi:10.1016/j.marchem.2005.06.004, 2006.

Balistrieri, L., Brewer, P. G., and Murray, J. W.: Scavenging residence times of trace-metals and surface-chemistry of sinking particles in the deep ocean, Deep-Sea Res., 28, 101-121, doi:10.1016/0198-0149(81)90085-6, 1981.

Bergquist, B. A., Wu, J., and Boyle, E. A.: Variability in oceanic dissolved iron is dominated by the colloidal fraction, Geochim. Cosmochim. Acta, 71, 2960-2974, 2007.

Blain, S., Queguiner, B., Armand, L., Belviso, S., Bombled, B., Bopp, L., Bowie, A., Brunet, C., Brussaard, C., Carlotti, F., Christaki, U., Corbiere, A., Durand, I., Ebersbach, F., Fuda, J. L., Garcia, N., Gerringa, L., Griffiths, B., Guigue, C., Guillerm, C., Jacquet, S., Jeandel, C., Laan, P., Lefevre, D., Lo Monaco, C., Malits, A., Mosseri, J., Obernosterer, I., Park, Y. H., Picheral, M., Pondaven, P., Remenyi, T., Sandroni, V., Sarthou, G., Savoye, N., Scouarnec, L., Souhaut, M., Thuiller, D., Timmermans, K., Trull, T., Uitz, J., van Beek, P., Veldhuis, M., Vincent, D., Viollier, E., Vong, L., and Wagener, T.: Effect of natural iron fertilization on carbon sequestration in the southern ocean, Nature, 446, 10701071, 2007.

Bonnet, S. and Guieu, C.: Dissolution of atmospheric iron in seawater, Geophys. Res. Lett., 31, L03303, doi:10.1029/2003g1018423, 2004.

Bonnet, S. and Guieu, C.: Atmospheric forcing on the annual iron cycle in the western mediterranean sea: A 1-year survey, J. Geophys. Res.-Oceans, 111, C09010, doi:10.1029/2005jc003213, 2006.

Boyd, P. W., Watson, A., Law, C. S., Abraham, E., Trull, T., Murdoch, R., Bakker, D. C. E., Bowie, A. R., Buesseler, K. O., Chang, H., Charette, M., Croot, P. L., Downing, K., Frew, R., Gall, M., Hadfield, M., Hall, J., Harvey, M., Jameson, G., LaRoche, J., Liddicoat, M., Ling, R., Maldonado, M., McKay, R. M., Nodder, S., Pickmere, S., Pridmore, R., Rintoul, S., Safi, K., Sutton, P., Strzepek, R., Tannenberger, K., Turner, S., Waite, A., and Zeldis, J.: Mesoscale iron fertilisation elevates phytoplankton stocks in the polar southern ocean, Nature, 407, 695-702, 2000.

Boyle, E. A., Chapnick, S. D., Bai, X. X., and Spivack, A.: Tracemetal enrichments in the mediterranean-sea, Earth Planet. Sci. Lett., 74, 405-419, doi:10.1016/s0012-821x(85)80011-x, 1985.

Bressac, M. and Guieu, C.: Organic complexation versus scavenging: What really happens to new atmospheric iron in the ocean surface?, Global Biogeochem. Cy., in revision, 2013.
Bressac, M., Guieu, C., Doxaran, D., Bourrin, F., Obolensky, G., and Grisoni, J.-M.: A mesocosm experiment coupled with optical measurements to assess the fate and sinking of atmospheric particles in clear oligotrophic waters, Geo-Mar. Lett., 32, 153 164, doi:10.1007/s00367-011-0269-4, 2012.

Bressac, M., Guieu, C., Doxoran, D., Bourrin, F., Leblond, N., and Ridame, C.: Quantification of the lithogenic carbon pump following a dust event, Biogeosciences (BG), in preparation, 2013.

Bruland, K. W., Franks, R. P., Knauer, G. A., and Martin, J. H.: Sampling and analytical methods for the determination of copper, cadmium, zinc, and nickel at the nanogram per liter level in seawater, Anal. Chimica Acta, 105, 233-245, doi:10.1016/s00032670(01)83754-5, 1979.

Brust, J. and Waniek, J. J.: Atmospheric dust contribution to deepsea particle fluxes in the subtropical northeast atlantic, Deep-Sea Res. Pt. I, 57, 988-998, doi:10.1016/j.dsr.2010.04.011, 2010.

Brust, J., Schulz-Bull, D. E., Leipe, T., Chavagnac, V., and Waniek, J. J.: Descending particles: From the atmosphere to the deep ocean-a time series study in the subtropical ne atlantic, Geophys. Res. Lett., 38, L06603, doi:10.1029/2010g1045399, 2011.

Buck, C. S., Landing, W. M., Resing, J. A., and Lebon, G. T.: Aerosol iron and aluminum solubility in the northwest pacific ocean: Results from the 2002 ioc cruise, Geochem. Geophy. Geosy., 7, Q04m07, doi:10.1029/2005gc000977, 2006.

Carr, M.-E., Friedrichs, M. A. M., Schmeltz, M., Noguchi Aita, M., Antoine, D., Arrigo, K. R., Asanuma, I., Aumont, O., Barber, R., Behrenfeld, M., Bidigare, R., Buitenhuis, E. T., Campbell, J., Ciotti, A., Dierssen, H., Dowell, M., Dunne, J., Esaias, W., Gentili, B., Gregg, W., Groom, S., Hoepffner, N., Ishizaka, J., Kameda, T., Le Quéré, C., Lohrenz, S., Marra, J., Mélin, F., Moore, K., Morel, A., Reddy, T. E., Ryan, J., Scardi, M., Smyth, T., Turpie, K., Tilstone, G., Waters, K., and Yamanaka, Y.: A comparison of global estimates of marine primary production from ocean color, Deep-Sea Res. Pt. II, 53, 741-770, doi:10.1016/j.dsr2.2006.01.028, 2006.

Caschetto, S. and Wollast, R.: Vertical distribution of dissolved aluminium in the mediterranean sea, Mar. Chem., 7, 141-155, doi:10.1016/0304-4203(79)90006-9, 1979.

Chou, L. and Wollast, R.: Biogeochemical behavior and mass balance of dissolved aluminum in the western mediterranean sea, Deep Sea Research Part II: Topical Studies in Oceanography, 44, 741-768, doi:10.1016/s0967-0645(96)00092-6, 1997.

Copin-Montegut, G., Courau, P., and Nicolas, E.: Distribution and transfer of trace elements in the western mediterranean, Mar. Chem., 18, 189-195, doi:10.1016/0304-4203(86)90007-1, 1986.

Croot, P. L. and Heller, M. I.: The importance of kinetics and redox in the biogeochemical cycling of iron in the surface ocean, Frontiers in Microbiology, 3, 219, doi:10.3389/fmicb.2012.00219, 2012.

Croot, P. L. and Johansson, M.: Determination of iron speciation by cathodic stripping voltammetry in seawater using the competing ligand 2-(2-thiazolylazo)-p-cresol (tac), Electroanalysis, 12, 565-576, 2000.

Croot, P. L., Bowie, A. R., Frew, R. D., Maldonado, M., Hall, J. A., Safi, K. A., La Roche, J., Boyd, P. W., and Law, C. S.: Retention of dissolved iron and $\mathrm{fe}^{i i}$ in an iron induced southern ocean phytoplankton bloom, Geophys. Res. Lett., 28, 34253428, doi:10.1029/2001g1013023, 2001. 
Croot, P. L., Streu, P., and Baker, A. R.: Short residence time for iron in surface seawater impacted by atmospheric dry deposition from saharan dust events, Geophys. Res. Lett., 31, L23S08, doi:10.1029/2004g1020153, 2004.

Croot, P. L., Passow, U., Assmy, P., Jansen, S., and Strass, V. H.: Surface active substances in the upper water column during a southern ocean iron fertilization experiment (eifex), Geophys. Res. Lett., 34, L03612, doi:10.1029/2006g1028080, 2007.

Cutter, G. A., Andersson, P., Codispoti, L., Croot, P. L., Francois, R., Lohan, M., Obata, H., and Rutgers van der Loeff, M.: Sampling and Sample-handling Protocols for GEOTRACES Cruises: http://www.geotraces.org/libraries/ documents/Intercalibration/Cookbook.pdf, 2010.

Dammshäuser, A., Wagener, T., and Croot, P. L.: Surface water dissolved aluminum and titanium: Tracers for specific time scales of dust deposition to the atlantic?, Geophys. Res. Lett., 38, L24601, doi:10.1029/2011g1049847, 2011.

Danielsson, L.-G., Magnusson, B., and Westerlund, S.: An improved metal extraction procedure for the determination of trace metals in sea water by atomic absorption spectrometry with electrothermal atomization, Analyt. Chimica Acta, 98, 47-57, doi:10.1016/s0003-2670(01)83237-2, 1978.

Duce, R. A., Liss, P. S., Merrill, J. T., Atlas, E. L., Buat-Menard, P., Hicks, B. B., Miller, J. M., Prospero, J. M., Arimoto, R., Church, T. M., Ellis, W., Galloway, J. N., Hansen, L., Jickells, T. D., Knap, A. H., Reinhardt, K. H., Schneider, B., Soudine, A., Tokos, J. J., Tsunogai, S., Wollast, R., and Zhou, M.: The atmospheric input of trace species to the world ocean, Glob. Biogeochem. Cy., 5, 193-259, doi:10.1029/91gb01778, 1991.

Emerson, S., Quay, P., Karl, D., Winn, C., Tupas, L., and Landry, M.: Experimental determination of the organic carbon flux from open-ocean surface waters, Nature, 389, 951-954, 1997.

Fischer, A. C., Kroon, J. J., Verburg, T. G., Teunissen, T., and Wolterbeek, H. T.: On the relevance of iron adsorption to container materials in small-volume experiments on iron marine chemistry: 55Fe-aided assessment of capacity, affinity and kinetics, Mar. Chem., 107, 533-546, 2007.

Giovagnetti, V., Brunet, C., Conversano, F., Tramontano, F., Obernosterer, I., Ridame, C., and Guieu, C.: Assessing the role of dust deposition on phytoplankton ecophysiology and succession in a low-nutrient low-chlorophyll ecosystem: A mesocosm experiment in the mediterranean sea, Biogeosciences Discuss., 9, 19199-19243, doi:10.5194/bgd-9-19199-2012, 2012.

Gledhill, M. and Buck, K. N.: The organic complexation of iron in the marine environment: A review, Front. Microbiol., 3, doi:10.3389/fmicb.2012.00069, 2012.

Grasshoff, K., Kremling, K., and Ehrhardt, M.: Methods of seawater analysis, Verlag Chemie, Weinheim, 1983.

Guerzoni, S., Molinaroli, E., Rossini, P., Rampazzo, G., Quarantotto, G., de Falco, G., and Cristini, S.: Role of desert aerosol in metal fluxes in the mediterranean area, Chemosphere, 39, 229246, doi:10.1016/s0045-6535(99)00105-8, 1999.

Guieu, C., Duce, R., and Arimoto, R.: Dissolved input of manganese to the ocean: Aerosol source, J. Geophys. Res., 99, 18789-18800, 1994.

Guieu, C., Loye-Pilot, M. D., and Ridame, C.: DUNE -a Dust experiment in a low Nutrient, low Chlorophyll Ecosystem - Quantifying the role of atmospheric input on marine ecosystem using large clean mesocosms, SOLAS Newsletter, 9, 36-37, 2009.
Guieu, C., Dulac, F., Desboeufs, K., Wagener, T., Pulido-Villena, E., Grisoni, J.-M., Louis, F., Ridame, C., Blain, S., Brunet, C., Nguyen, E. B., Tran, S., Labiadh, M., and Dominici, J.M.: Large clean mesocosms and simulated dust deposition: A new methodology to investigate responses of marine oligotrophic ecosystems to atmospheric inputs, Biogeosciences, 7, 27652784, doi:10.5194/bg-7-2765-2010, 2010.

Guieu, C., Dulac, F., Ridame, C., and Pondaven, P.: Introduction to the DUNE project: a DUst experiment in a low Nutrient, low chlorophyll Ecosystem, Biogeosciences (BG), in preparation, 2013.

Heller, M. I. and Croot, P. L.: Kinetics of superoxide reactions with dissolved organic matter in tropical Atlantic surface waters near Cape Verde (TENATSO), J. Geophys. Res., 115, C12038, doi:10.1029/2009jc006021, 2010.

Herut, B., Zohary, T., Krom, M. D., Mantoura, R. F. C., Pitta, P., Psarra, S., Rassoulzadegan, F., Tanaka, T., and Frede Thingstad, T.: Response of east mediterranean surface water to saharan dust: On-board microcosm experiment and field observations, DeepSea Res. Pt. II, 52, 3024-3040, doi:10.1016/j.dsr2.2005.09.003, 2005.

Honeyman, B. D. and Santschi, P. H.: Coupling adsorption and particle aggregation: Laboratory studies of "colloidal pumping" using iron-59fe-labeled hematite, Environ. Sci. Technol., 25, 17391747, doi:10.1021/es00022a010, 1991.

Honeyman, B. D., Balistieri, L. S., and Murray, J. W.: Oceanic trace metal scavenging: The importance of particle concentration, Deep-Sea Res., 35, 227-246, 1988.

Hunter, K. A.: The adsorptive properties of sinking particles in the deep ocean, Deep-Sea Res., 30, 669-675, 1983.

Hydes, D. J. and Liss, P. S.: Fluorimetric method for the determination of low concentrations of dissolved aluminium in natural waters, Analyst, 101, 922-931, 1976.

Hydes, D. J., de Lange, G. J., and de Baar, H. J. W.: Dissolved aluminium in the mediterranean, Geochim. Cosmochim. Acta, 52, 2107-2114, doi:10.1016/0016-7037(88)90190-1, 1988.

Jickells, T. D.: The inputs of dust derived elements to the sargasso sea; a synthesis, Mar. Chem., 68, 5-14, 1999.

Jickells, T., Church, T., Veron, A., and Arimoto, R.: Atmospheric inputs of manganese and aluminum to the sargasso sea and their relation to surface-water concentrations, Mar. Chem., 46, 283292, doi:10.1016/0304-4203(94)90083-3, 1994.

Jickells, T. D., An, Z. S., Andersen, K. K., Baker, A. R., Bergametti, G., Brooks, N., Cao, J. J., Boyd, P. W., Duce, R. A., Hunter, K. A., Kawahata, H., Kubilay, N., laRoche, J., Liss, P. S., Mahowald, N., Prospero, J. M., Ridgwell, A. J., Tegen, I., and Torres, R.: Global iron connections between desert dust, ocean biogeochemistry, and climate, Science, 308, 67-71, doi:10.1126/science.1105959, 2005.

Johnson, K. S., Elrod, V., Fitzwater, S., Plant, J., Boyle, E., Bergquist, B., Bruland, K., Aguilar-Islas, A., Buck, K., Lohan, M., Smith, G. J., Sohst, B., Coale, K., Gordon, M., Tanner, S., Measures, C., Moffett, J., Barbeau, K., King, A., Bowie, A., Chase, Z., Cullen, J., Laan, P., Landing, W., Mendez, J., Milne, A., Obata, H., Doi, T., Ossiander, L., Sarthou, G., Sedwick, P., Van den Berg, S., Laglera-Baquer, L., Wu, J.-f., and Cai, Y.: Developing standards for dissolved iron in seawater, Eos Trans. AGU, 88, 2007. 
Journet, E., Desboeufs, K. V., Caquineau, S., and Colin, J.-L.: Mineralogy as a critical factor of dust iron solubility, Geophys. Res. Lett., 35, L07805, doi:10.1029/2007g1031589, 2008.

Klinkhammer, G. P.: Determination of manganese in sea water by flameless atomic absorption spectrometry after preconcentration with 8-hydroxyquinoline in chloroform, Analytical Chemistry, 52, 117-120, doi:10.1021/ac50051a028, 1980.

Kremling, K. and Petersen, H.: The distribution of zinc, cadmium, copper, manganese and iron in waters of the open mediterranean sea, Meteor Forschungsergeb Reihe A/B, 23, 5-14, 1981.

Laghdass, M., Blain, S., Besseling, M., Catala, P., Guieu, C., and Obernosterer, I.: Effects of saharan dust on the microbial community during a large in situ mesocosm experiment in the nw mediterranean sea, Aquat. Microb. Ecol., 62, 201-213, doi:10.3354/Ame01466, 2011.

Landing, W. M. and Paytan, A.: Marine chemistry special issue: Aerosol chemistry and impacts on the ocean, Mar. Chem., 120, 1-3, doi:10.1016/j.marchem.2010.04.001, 2010.

Liu, X. and Millero, F. J.: The solubility of iron in seawater, Mar. Chem., 77, 43-54, 2002.

Longhurst, A., Sathyendranath, S., Platt, T., and Caverhill, C.: An estimate of global primary production in the ocean from satellite radiometer data, J. Plankt. Res., 17, 1245-1271, doi:10.1093/plankt/17.6.1245, 1995.

Mackenzie, F. T., Stoffyn, M., and Wollast, R.: Aluminum in seawater: Control by biological activity, Science, 199, 680-682, doi:10.1126/science.199.4329.680, 1978.

Measures, C. I., Sato, T., Vink, S., Howell, S., and Li, Y. H.: The fractional solubility of aluminium from mineral aerosols collected in hawaii and implications for atmospheric deposition of biogeochemically important trace elements, Mar. Chem., 120, 144-153, doi:10.1016/j.marchem.2009.01.014, 2010.

Mendez, J., Guieu, C., and Adkins, J.: Atmospheric input of manganese and iron to the ocean: Seawater dissolution experiments with saharan and north american dusts, Mar. Chem., 120, 34-43, doi:10.1016/j.marchem.2008.08.006, 2010.

Millot, C.: Circulation in the western mediterranean sea, Journal of Marine Systems, 20, 423-442, doi:10.1016/s09247963(98)00078-5, 1999.

Moffett, J. W.: The importance of microbial Mn oxidation in the upper ocean: a comparison of the Sargasso Sea and equatorial Pacific, Deep-Sea Res. Pt. I, 44, 1277-1291, doi:10.1016/s09670637(97)00032-0, 1997.

Moore, J. K., Doney, S. C., Lindsay, K., Mahowald, N., and Michaels, A. F.: Nitrogen fixation amplifies the ocean biogeochemical response to decadal timescale variations in mineral dust deposition, Tellus B, 58, 560-572, 2006.

Moran, S. B. and Moore, R. M.: Temporal variations in dissolved and particulate aluminum during a spring bloom, Estuarine, Coastal and Shelf Science, 27, 205-215, doi:10.1016/02727714(88)90090-x, 1988.

Morgan, J. J.: Kinetics of reaction between o2 and mn(ii) species in aqueous solutions, 69, 35-48, doi:10.1016/j.gca.2004.06.013,, 2005.

Morley, N. H., Burton, J. D., Tankere, S. P. C., and Martin, J. M.: Distribution and behaviour of some dissolved trace metals in the western mediterranean sea, Deep-Sea Res. Pt. II, 44, 675-691, doi:10.1016/s0967-0645(96)00098-7, 1997.
Nealson, K. H., Tebo, B. M., Rosson, R. A., and Allen, I. L.: Occurrence and mechanisms of microbial oxidation of manganese, in: Advances in applied microbiology, Academic Press, 279-318, 1988.

Noble, A. E., Saito, M. A., Maiti, K., and Benitez-Nelson, C. R.: Cobalt, manganese, and iron near the hawaiian islands: A potential concentrating mechanism for cobalt within a cyclonic eddy and implications for the hybrid-type trace metals, Deep-Sea Res. Pt. II, 55, 1473-1490, doi:10.1016/j.dsr2.2008.02.010, 2008.

Obata, H., Shitashima, K., Isshik, K., and Nakayama, E.: Iron, manganese and aluminum in upper waters of the western south pacific ocean and its adjacent seas, J. Oceanogr., 64, 233-245, 2008.

Pulido-Villena, E., Baudoux, A.-C., Obernosterer, I., Catala, P., and Guieu, C.: Enhanced carbon remineralization by the microbial food web after dust deposition: Results from a mesocosm study, Biogeosciences Discuss., in preparation, 2013.

Roitz, J. S. and Bruland, K. W.: Determination of dissolved manganese(II) in coastal and estuarine waters by differential pulse cathodic stripping voltammetry, Analyt. Chimica Acta, 344, 175180, doi:10.1016/s0003-2670(97)00041-x, 1997.

Saito, M. A. and Moffett, J. W.: Temporal and spatial variability of cobalt in the atlantic ocean, Geochim. Cosmochim. Acta, 66, 1943-1953, doi:10.1016/s0016-7037(02)00829-3, 2002.

Sañudo-Wilhelmy, S. A., Rivera-Duarte, I., and Russell Flegal, A.: Distribution of colloidal trace metals in the san francisco bay estuary, Geochim. Cosmochim. Acta, 60, 4933-4944, doi:10.1016/s0016-7037(96)00284-0, 1996.

Sarthou, G. and Jeandel, C.: Seasonal variations of iron concentrations in the ligurian sea and iron budget in the western mediterranean sea, Mar. Chem., 74, 115-129, 2001.

Sedwick, P. N., Sholkovitz, E. R., and Church, T. M.: Impact of anthropogenic combustion emissions on the fractional solubility of aerosol iron: Evidence from the sargasso sea, Geochem. Geophy. Geosy., 8, Q10Q06, doi:10.1029/2007gc001586, 2007.

Sherrell, R. M. and Boyle, E. A.: Zinc, chromium, vanadium and iron in the mediterranean sea, Deep-Sea Res. Pt. A, 35, 13191334, doi:10.1016/0198-0149(88)90085-4, 1988.

Sholkovitz, E. R., Sedwick, P. N., Church, T. M., Baker, A. R., and Powell, C. F.: Fractional solubility of aerosol iron: Synthesis of a global-scale data set, Geochim. Cosmochim. Acta, 89, 173-189, doi:10.1016/j.gca.2012.04.022, 2012.

Spokes, L. J., and Jickells, T. D.: Factors controlling the solubility of aerosol trace metals in the atmosphere and on mixing into seawater, Aquat. Geochem., 1, 355-374, doi:10.1007/bf00702739, 1996.

Statham, P. J., Burton, J. D., and Hydes, D. J.: Cd and Mn in the Alboran Sea and adjacent North Atlantic: geochemical implications for the Mediterranean, Nature, 313, 565-567, 1985.

Stumm, W. and Morgan, J. J.: Aquatic chemistry, WileyInterscience, New York, 1022 pp., 1996.

Sunda, W. G. and Huntsman, S. A.: Microbial oxidation of manganese in a north carolina estuary, Anglais, 32, 552-564, 1987.

Sunda, W. G. and Huntsman, S. A.: Effect of sunlight on redox cycles of manganese in the southwestern sargasso sea, Deep-Sea Res. Pt. A, 35, 1297-1317, 1988.

Sunda, W. G. and Huntsman, S. A.: Diel cycles in microbial manganese oxidation and manganese redox speciation in coastal waters of the bahama-islands, Limnol. Oceanogr., 35, 325-338, 
1990.

Turekian, K. K.: The fate of metals in the oceans, Geochim. Cosmochim. Acta, 41, 1139-1144, doi:10.1016/00167037(77)90109-0, 1977.

van den Berg, C. M. G., Boussemart, M., Yokoi, K., Prartono, T., and Campos, M. L. A. M.: Speciation of aluminium, chromium and titanium in the nw mediterranean, Mar. Chem., 45, 267-282, doi:10.1016/0304-4203(94)90074-4, 1994.

van den Berg, C. M. G.: Evidence for organic complexation of iron in seawater, Mar. Chem., 50, 139-157, 1995.

von Langen, P. J., Johnson, K. S., Coale, K. H., and Elrod, V. A.: Oxidation kinetics of manganese (II) in seawater at nanomolar concentrations, Geochim. Cosmochim. Acta, 61, 4945-4954, doi:10.1016/s0016-7037(97)00355-4, 1997.

Wagener, T., Pulido-Villena, E., and Guieu, C.: Dust iron dissolution in seawater: Results from a one-year time-series in the mediterranean sea, Geophys. Res. Lett., 35, L16601, doi:10.1029/2008GL034581, 2008.
Wagener, T., Guieu, C., and Leblond, N.: Effects of dust deposition on iron cycle in the surface mediterranean sea: Results from a mesocosm seeding experiment, Biogeosciences, 7, 3769-3781, doi:10.5194/bg-7-3769-2010, 2010.

Ye, Y., Wagener, T., Völker, C., Guieu, C., and Wolf-Gladrow, D. A.: Dust deposition: Iron source or sink? A case study, Biogeosciences, 8, 2107-2124, doi:10.5194/bg-8-2107-2011, 2011.

Yeats, P. A. and Strain, P. M.: The oxidation of manganese in seawater: Rate constants based on field data, Estuarine, Coast. Shelf Sci., 31, 11-24, 1990.

Yoon, Y. Y., Martin, J. M., and Cotte, M. H.: Dissolved trace metals in the western mediterranean sea: Total concentration and fraction isolated by c18 sep-pak technique, Mar. Chem., 66, 129148, doi:10.1016/s0304-4203(99)00033-x, 1999.

Zhuang, G., Yi, Z., Duce, R. A., and Brown, P. R.: Chemistry of iron in marine aerosols, Global Biogeochem. Cy., 6, 161-173, doi:10.1029/92gb00756, 1992. 